\title{
Overcoming chemotherapy drug resistance by targeting inhibitors of apoptosis proteins (IAPs)
}

\author{
Rama Rathore $^{1} \cdot$ Jennifer E. McCallum $^{2} \cdot$ Elizabeth Varghese $^{2} \cdot$ Ana-Maria Florea $^{3}$. \\ Dietrich Büsselberg ${ }^{2}[$
}

Published online: 19 April 2017

(C) The Author(s) 2017. This article is an open access publication

\begin{abstract}
Inhibitors of apoptosis (IAPs) are a family of proteins that play a significant role in the control of programmed cell death (PCD). PCD is essential to maintain healthy cell turnover within tissue but also to fight disease or infection. Uninhibited, IAPs can suppress apoptosis and promote cell cycle progression. Therefore, it is unsurprising that cancer cells demonstrate significantly elevated expression levels of IAPs, resulting in improved cell survival, enhanced tumor growth and subsequent metastasis. Therapies to target IAPs in cancer has garnered substantial scientific interest and as resistance to anti-cancer agents becomes more prevalent, targeting IAPs has become an increasingly attractive strategy to re-sensitize cancer cells to chemotherapies, antibody based-therapies and TRAIL therapy. Antagonism strategies to modulate the actions of XIAP, cIAP1/2 and survivin are the central focus of current research and this review highlights advances within this field with particular emphasis upon the development and specificity of second mitochondria-derived activator of caspase (SMAC) mimetics (synthetic analogs of endogenously expressed inhibitors of IAPs SMAC/DIABLO). While we highlight the potential of SMAC mimetics as effective single agent or combinatory therapies to treat cancer we also discuss the likely clinical implications of resistance to
\end{abstract}

Rama Rathore and Jennifer E. McCallum have contributed equally to this work.

Dietrich Büsselberg

dib2015@qatar-med.cornell.edu

1 College of Literature, Sciences and the Arts, University of Michigan-Ann Arbor, Ann Arbor, MI 48109, USA

2 Weill Cornell Medicine-Qatar, P.O.B. 24144, Doha, Qatar

3 Institute of Neuropathology, Heinrich Heine University Düsseldorf, Moorenstraße 5, 40225 Düsseldorf, Germany
SMAC mimetic therapy, occasionally observed in cancer cell lines.

Keywords Chemotherapy resistance $\cdot$ Inhibitors of apoptosis proteins $\cdot$ Combination therapy $\cdot$ Intrinsic apoptotic pathway $\cdot$ Extrinsic apoptotic pathway

$\begin{array}{ll}\text { Abbreviations } & \\ \text { AIF } & \text { Apoptosis inducing factor } \\ \text { ALL } & \text { Acute lymphoblastic leukemia } \\ \text { AML } & \text { Acute myeloid leukemia } \\ \text { ANT } & \text { Adenine nucleotide translocator } \\ \text { Apaf1 } & \text { Apoptosis protease activating factor 1 } \\ \text { API2 } & \text { Apoptotic protein inhibitor 2 } \\ \text { Asp } & \text { Aspartate } \\ \text { AVPF } & \text { Alanine-valine-phenylalanine-for- } \\ & \text { mic acid } \\ \text { AVPI } & \text { Alanine-valine-phenylalanine-iso- } \\ & \text { leucine } \\ \text { Bad } & \text { Bcl-2 associated death promoter } \\ \text { Bak } & \text { Bcl-2 antagonist and killer } \\ \text { Bax } & \text { Bcl-2 associated X protein } \\ \text { Bcl-2 proteins } & \text { B cell lymphoma 2 proteins } \\ \text { Bcl-Xl } & \text { B cell lymphoma-extra large } \\ \text { Bid } & \text { BH3 interacting-domain death } \\ & \text { agonist } \\ \text { Bim } & \text { Bcl-2-like protein 11 } \\ \text { BIR domain } & \text { Baculovirus IAP repeat domains } \\ \text { BIRC } & \text { Baculoviral inhibitors of apoptosis } \\ & \text { repeat containing proteins } \\ \text { Bmf } & \text { Bcl-2 modifying factor } \\ \text { BRUCE } & \text { BIR-containing ubiquitin conjugating } \\ & \text { enzyme } \\ \text { BZM } & \text { Bortezomib } \\ \text { CAD } & \text { Caspase activated DNAase } \\ & \end{array}$




\begin{tabular}{|c|c|c|c|}
\hline CARD & Caspase-recruitment domain & NFkB pathway & Nuclear factor kappa beta pathway \\
\hline CDDP & Cisplatin & Omi/HtrA2 & Temperature requirement protein $\mathrm{A} 2$ \\
\hline CD95 & Cluster of differentiation 95 & OMM & High outer mitochondrial membrane \\
\hline Chk1 & Checkpoint kinase 1 & PBR & Peripheral benzodiazepine receptor \\
\hline \multirow[t]{2}{*}{ cIAP1 } & Cellular inhibitor of apoptosis protein & PBOX-15 & Pyrrolo-1,5-benzoxazepine \\
\hline & 1 & $\mathrm{PM}$ & Plasma membrane \\
\hline cIAP2 & $\begin{array}{l}\text { Cellular inhibitor of apoptosis protein } \\
2\end{array}$ & PTPs & $\begin{array}{l}\text { Permeability transition pores } \\
\text { (mitochondrial) }\end{array}$ \\
\hline CK & Creatine kinase & RING domain & Really interesting new gene domain \\
\hline CLL & Chronic lymphocytic leukemia & \multirow[t]{2}{*}{ RIPK1 } & \multirow{2}{*}{$\begin{array}{l}\text { Receptor-interacting serine/threo- } \\
\text { nine-protein kinase } 1\end{array}$} \\
\hline CML & Chronic myelogenous leukemia & & \\
\hline CypD & Cyclophilin D & RNAi & Ribonucleic acid interference \\
\hline Cys & Cysteine & ROS & Reactive oxygen species \\
\hline Cyt c & Cytochrome c & SADS & Small accelerator of death signaling \\
\hline dATP & Deoxyadenosine triphosphate & SAHA & Suberoylanilide hydroxamic acid \\
\hline DISC & Death-inducing signaling complex & siRNA & Small interfering RNA \\
\hline DR4 & Death receptor 4 & \multirow[t]{3}{*}{ SMAC/DIABLO } & Second mitochondrial derived activa- \\
\hline DR5 & Death receptor 5 & & tor of caspase/direct inhibitor of \\
\hline FADD & $\begin{array}{l}\text { Fas-associated protein with death } \\
\text { domain }\end{array}$ & & $\begin{array}{l}\text { apoptosis-binding with a low isoelec- } \\
\text { tric point }\end{array}$ \\
\hline FasL/R & Fas ligand/receptor & tBid & Truncated-bid \\
\hline FLASH & Flice-associated huge protein & TNF & Tumor necrosis factor \\
\hline \multirow[t]{2}{*}{ FPVA } & Formic & $\mathrm{TNF}-\alpha$ & Tumor necrosis factor alpha \\
\hline & acid-phenylalanine-valine-alanine & $\mathrm{TNF} \alpha \mathrm{R} 1$ & TNF- $\alpha$ receptor 1 \\
\hline $\mathrm{HCC}$ & Hepatocellular carcinoma cells & TNFR & TNF- $\alpha$ receptor complex \\
\hline \multirow[t]{2}{*}{ HER2 } & Human epidermal growth factor & TP53 & Tumor protein 53 \\
\hline & receptor 2 & \multirow[t]{2}{*}{ TRADD } & TNFRSF1A-associated via death \\
\hline HK & Hexokinase & & domain \\
\hline HIAP2 & Human inhibitor of apoptosis 2 & TRAF2/5 & TNF-receptor associated factor $2 / 5$ \\
\hline hILP1/2 & Human IAP-like protein $1 / 2$ & \multirow{2}{*}{ TRAIL } & TNF-related apoptosis-inducing \\
\hline HRPC & Human refractory prostate cancer & & ligand \\
\hline IAPs & Inhibitors of apoptosis proteins & TRAILRI/II & TRAIL receptor I and II \\
\hline IBM & IAP binding motifs & \multirow[t]{2}{*}{ Ts-IAP } & Testis-specific inhibitor of apoptosis \\
\hline ILP-1/2 & IAP-like protein $1 / 2$ & & protein \\
\hline IMM & Inner mitochondrial membrane & VDAC2 & Voltage-dependent anion channel 2 \\
\hline \multirow{2}{*}{ IPVA } & Isoleucine-phenylalanine-valine-ala- & XAF1 & XIAP-associated factor 1 \\
\hline & nine & \multirow{2}{*}{ XIAP } & $\mathrm{X}$-linked inhibitor of apoptosis \\
\hline IV & Intravenous & & protein \\
\hline KIAP & Kidney inhibitor of apoptosis protein & XLP & $\mathrm{X}$-linked proliferative disorder \\
\hline
\end{tabular}

LRR domain Leucine-rich repeat domain

MALT Lymphoma Mucosa-associated lymphoid tissue lymphoma

MAP/Akt proteins Microtubule associated proteins/protein kinase $\mathrm{B}$

Mcl-1 Myeloid cell leukemia 1

MDS Myelodysplastic syndromes

MIHA/B/C Mammalian homolog of IAP A/B/C

ML-IAP Melanoma inhibitor of apoptosis

MOMP Mitochondrial outer membrane permeabilization

NACHT domain NAIP, C2TA, HET-E and TP1 domain

NAIP Neuronal apoptosis inhibitory protein

\section{Introduction}

Cancer develops when cell growth exceeds cell death following a loss in control of the fundamental cellular checkpoints required to maintain healthy tissue turnover. This uninhibited proliferative capacity follows a dysregulation in oncogenic expression that results in tumor formation. In healthy cells, many of these processes give rise to stimuli that promote the induction of apoptosis, most prominently regulated by the $\mathrm{B}$ cell lymphoma 2 (Bcl-2) family of proteins [1]. However, in cancer pro-apoptotic factors are suppressed and anti-apoptotic proteins, such as the inhibitors 
of apoptosis proteins (IAPs) are upregulated, promoting uncontrolled cell division [2]. This excessive rate of cell proliferation gives rise to a hypoxic microenvironment and a dysregulation in growth factors, such as vascular endothelial growth factor (VEGF), that promote angiogenesis and genetic adaptations that can permit a tumor to thrive [3].

In cancer treatment, this dysregulation is targeted via multi-therapeutic approaches that include antibody-based, chemo- and radio-therapy. Most recent data from clinical trials suggest that both chemotherapy and radiation remain best first line therapies for aggressive lung cancer [4], reducing tumor size via stress induced apoptosis following direct and irreparable physical or chemical damage to DNA [5]. Whilst these approaches can be effective in the short term, the maximal dosages required to maintain anticancer agent or radiation effectiveness can, over time, give rise to cancer cells that exhibit chemo- and radio-resistance. Evidence suggests that some high dosage chemotherapy leads to caspase-independent necroptotic cell death, but it remains unclear if toxicity to healthy cells may be a compromising factor in its effectiveness [6]. Some cancer cell types exhibit intrinsic resistance to chemotherapy drugs, often attributed to high endogenous expression of drug efflux transporters such as MDR1 [7] and therapies targeting efflux systems are now in their third generation of development [8]. To combat both intrinsic and acquired chemoresistance, and thus prevent the eventual invincibility of cancer cells, it is important to better understand the role that caspase-mediated apoptosis plays in cancer agent mediated cell death pathways and chemoresistance.

In line with this, the expression and function of antiapoptotic and pro-apoptotic proteins have long been considered as potential strategies to target cancer pathogenesis via inhibitors and activators, respectively [9]. Already in combinatory cancer treatment, data from clinical studies suggest that classical chemotherapeutic drugs such as paclitaxel exert a synergetic action with pro-apoptotic agents like bortezomib to improve patient survival in radio-resistant non-small cell lung cancer [10]. In the same regard, it has been proposed that targeting IAPs could be equally helpful in combinatory therapy against cancer. Furthermore, modulation of their expression can facilitate direct targeting of the cell's apoptotic machinery to improve cell death [11]. In relation to chemo-sensitization, IAP modulation is particularly attractive because it bypasses upstream signaling pathways that may be impaired by resistance focusing on target initiator and effector caspases.

This review focuses on the role of IAPs in drug resistance and how to overcome it. To address this, the merits of mono-therapy with IAP-antagonists and combinatorial treatments with chemotherapeutic agents will be discussed. Within a wider perspective, the role of other small molecular inhibitors used in cancer treatment and their potential for co-treatment to target IAPs will be explored. Furthermore, given that some cancer cell types exhibit intrinsic resistance, it will explore the consequences of acquired resistance to IAP-antagonists and small molecular inhibitors in cancer treatment.

The central questions of this review are:

1. How best to target IAPs to overcome drug resistance?

2. How to tackle acquired resistance to IAP antagonism?

These are important questions in the field of cancer treatment and their answers will help to develop more efficient therapies for patients with acquired and intrinsic chemoresistance. Moreover, enhanced therapeutic approaches may improve patient survival in previously difficult to treat or aggressive cancers.

\section{Apoptosis pathways and cancer}

Cancer cells are more resistant to apoptotic cell death, allowing them to bypass critical biological checkpoints that normally maintain cell turnover in healthy tissues. Specifically, checkpoints can fail following an introduction of mutations in apoptotic genes such as p53, or DNArepair genes like Brac1/2 [12]. Given this, it is unsurprising that the administration of high dose anti-cancer therapies required to kill defective cells can indirectly induce apoptotic cell death in 'vulnerable' healthy tissues, producing unwanted side effects. For example, the effect of platinumbased chemotherapy on gastrointestinal tissue health is of particular concern and can be a major hindrance to the success of therapeutic regimens in the clinic [13]. Taking this together, it is suggested that direct manipulation of apoptotic pathways via IAP antagonism can offer a safer alternative that has limited effect on apoptosis in non-cancer cells that do not highly express IAPs [14].

There are two major ways in which caspase-dependent apoptosis can be induced; the first is via an activation of the intrinsic apoptotic pathway (also known as the mitochondrial apoptotic pathway) and the second involves activation of the extrinsic pathway (also known as the death receptor or transmembrane apoptotic pathway) [15] (Fig. 1). Though induced differently, cross-talk can facilitate amplification of the extrinsic pathway via the intrinsic pathway, known as the mitochondrial amplification loop [16]. Crucially, both pathways converge at the effector caspase level. Initiator caspases involved in the extrinsic pathway are caspase 8 and caspase 10, while the caspases involved in the intrinsic pathway are caspase 9 and 2. Caspase 3 and 7 are terminal effectors that execute apoptosis in response to stimuli from both intrinsic and extrinsic pathways. Evidence suggests the role of effector 


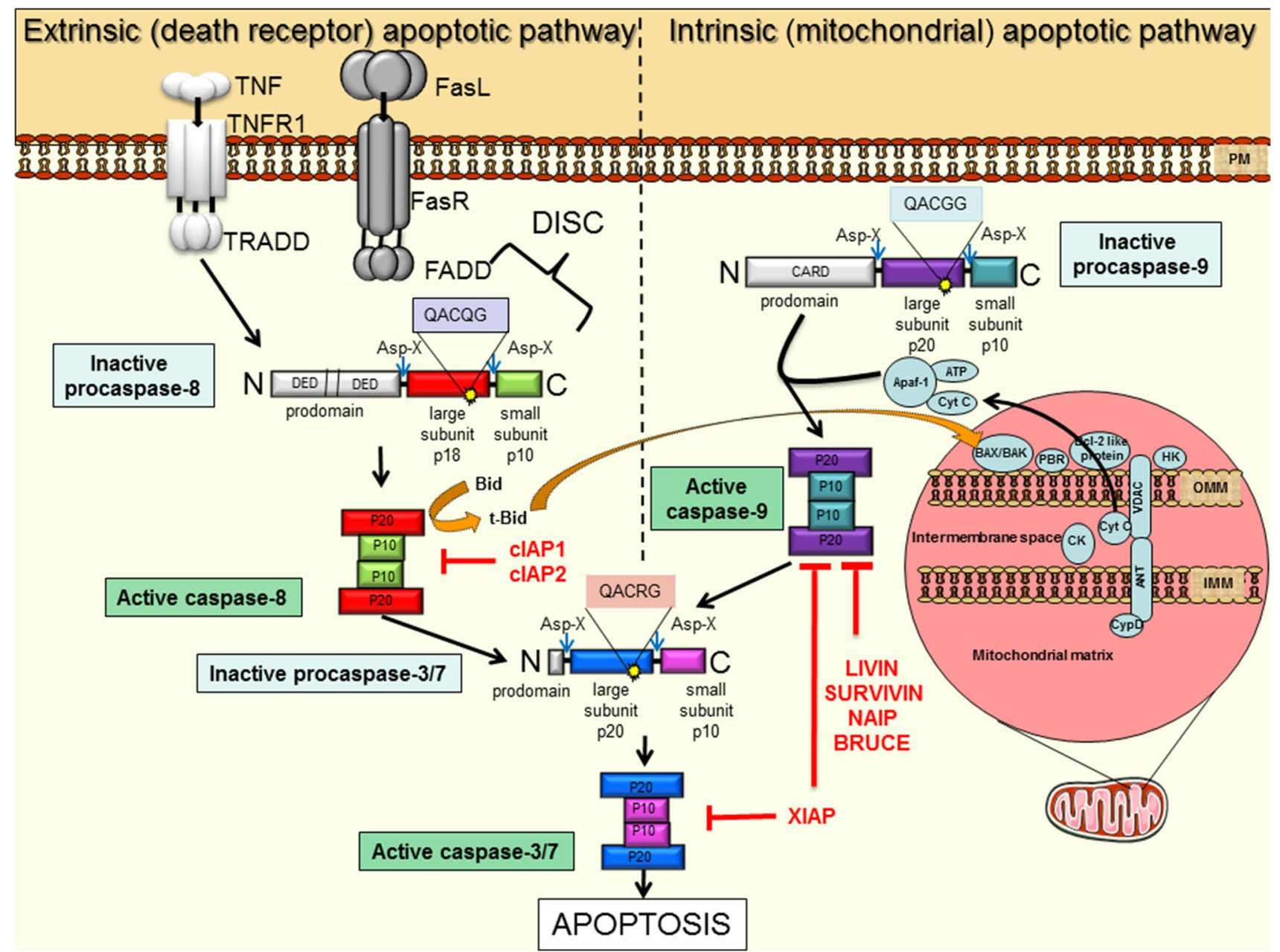

Fig. 1 Schematic illustration of the extrinsic and intrinsic apoptotic pathways, as well as the inhibitory effect of various IAPs on proapoptotic molecules. Extrinsic apoptotic pathway initiated by binding of death ligands, such as FasL or tumor necrosis factor (TNF) to death receptors located on the plasma membrane. This reaction is followed by the recruitment and binding of molecules like Fas-associated death domain protein (FADD) or tumor necrosis factor receptor type 1-associated death domain protein (TRADD) to the cytosolic domain of death receptors. Death-inducing signaling complex (DISC) is formed by death receptor, FADD and caspase 8. DISC formation initiates the signal transduction that culminates in apoptosis via caspase 3/7 activation. Active caspases can enhance apoptosis via cleavage of Bid to tBid; a cross-talk facilitator that mediates the mito-

caspases are extremely wide ranging and their protease activity has been demonstrated in $>400$ distinct substrates. Examples include reduction of cellular adhesion proteins such as $\alpha$-adducin and $\beta$-catenin to initiate cell detachment, to subsequent and systematic 'cell demolition' via targeting of scaffolding proteins like ROCK and chemotactic factor release that encourages the infiltration of phagocytic cells $[17,18]$. chondrial amplification loop. The truncated Bid (t-Bid) promotes the release of cytochrome c, via Bax, in mitochondria. The intrinsic pathway, is initiated within at the outer mitochondrial membrane (OMM) in response to cellular stress. As a result, these mediate mitochondrial permeability via interaction 'pro-apoptotic' $\mathrm{Bcl}-2$ proteins to stimulate release of cytochrome $\mathrm{c}$ and SMAC, which bind and inhibit IAPs. Cytochrome c, Apaf-1 and ATP binds to pro caspase 9 leading to apoptosome formation and activation of caspase 9, which in turn activate caspase 3 permitting the cell to proceed to apoptosis. IAPs are endogenous inhibitors of apoptosis identified in humans. The family members XIAP, cIAP1, cIAP2, NAIP, Livin and Survivin and BRUCE can bind caspases to block apoptosis. Importantly, their dysregulated expression is associated with cancer and chemoresistance

\section{The extrinsic apoptotic pathway}

The extrinsic pathway is activated by the binding of 'death' ligands to transmembrane receptors. The most prominent examples of these include the trimeric Fas ligand (FasL) and tumor necrosis factor (TNF), which bind to the Fas receptor (CD95/apoptosis-1R) and the tumor necrosis factor receptor (TNFR), respectively (Fig. 1). During receptor 
activation, the cytoplasmic domain of the ligand bound receptor complex associates with the death domain (FADD) of an adaptor molecule (Fas-associated protein) to enable binding to caspase 8 . This facilitates oligomerization and association of death domains on the adaptor molecules with those on the zymogenic pro-caspase 8. Together they form the death-inducing signaling complex (DISC) [19]. DISC mediates autocatalysis and thus, activation of pro-caspase 8 to caspase 8 which initiates the signaling cascade resulting in auto-activation of terminal effector caspases 3 or 7 , responsible for the definitive apoptosis signal.

A similar pathway is activated when TNF binds to TNFR, instead promoting association of the TNFR cytoplasmic domain with adaptor molecule TRADD (TNFRSF1A associated via death domain) and pro-caspase 8 [19]. Other intracellular signaling proteins associated with this pathway can either be pro- or anti-apoptotic in nature. For example, the Flice-associated huge protein (FLASH) and the small accelerator of death signaling (SADS) are understood to aid recruitment of pro-caspase 8 to the DISC complex, promoting apoptosis [20]. On the other hand, dysregulation of expression of the protein Bid, responsible for cross-talk between the extrinsic and intrinsic apoptotic pathway (activating the mitochondrial amplification loop), has been shown to potentiate apoptotic survival in hepatocytes [21].

\section{The intrinsic apoptotic pathway}

The intrinsic apoptotic pathway is controlled by the Bcl-2 superfamily that initiate the release of pro-apoptotic proteins from the mitochondrial intra-membrane space [22] (Fig. 1). This includes the efflux of cytochrome c (Cyto c), second mitochondria-derived activator of caspase/direct inhibitor of apoptosis-binding protein with a low isoelectric point (SMAC/DIABLO) and high temperature requirement protein $\mathrm{A} 2$ (Omi/HtrA2). Bax proteins, belonging to the Bcl-2 superfamily (discussed further, Fig. 1.) are understood to mediate the opening mitochondrial permeability transition pores (PTPs), disrupting the mitochondrial transmembrane potential and permeability [22]. Often found to be upregulated in cancer and chemoresistance [23], antiapoptotic Bcl-2 proteins such as Bcl-2, Bcl-XL and Mcl-1 inhibit Bax activation [22].

Currently, the exact mechanism of Cyto c release from the mitochondrial membrane space into the cytosol is not completely understood. Specifically, it is not clear if Cyto $\mathrm{c}$ release precedes or follows the opening of PTPs. While the general consensus suggests that $\mathrm{Bcl}-2$ proteins facilitate pore opening [24], some research suggests that Cyto c play a role in maintaining the mitochondrial membrane potential and drives ATP synthesis following an opening of the pores [25]. There are three major types of Bcl-2 protein families; 'the Bcl-2 anti-apoptotic proteins', 'the multi-domain proapoptotic proteins' and the 'BH3-only pro-apoptotic proteins'. The most prominent, Bax and Bak, belong to the 'multi-domain' family and their pro-apoptotic effect can be augmented by members of the 'BH3-only' family. BH3only proteins such as Bim, Bmf, Bad, Bid and Noxa also activate apoptotic machinery by neutralizing the anti-apoptotic Bcl-2 proteins [26].

As previously noted, Bax proteins permeabilize the outer mitochondrial membrane and it is thought that this occurs following translocation of monomeric Bax from the cytosol to the mitochondria [27]. It is still unclear what promotes this translocation, but evidence suggests that alterations in $\mathrm{pH}$ may be of importance [28]. Evidence also suggests that Bax undergoes a conformational change, oligomerizes with Bak and undergoes insertion into the outer mitochondrial membrane via it carboxyl terminus [29]. This is a rapid association mediated by a pro-apoptotic Bcl-2 protein called tBid, which can sometimes be inhibited when tBid is bound to Bcl-XL [30]. Contrastingly, Bax can be anchored to voltage-dependent anion channel 2 (VDAC2) on the outer mitochondrial membrane, preventing pore opening [31]. Most recent evidence suggests that VDAC may provide the molecular platform for Bax retrotranslocation to the cytosol following the initiation of pro-survival pathways [32].

Cyto c release into the cytosol is facilitated by its binding to dATP and apoptosis protease activating factor 1 (Apaf1) to form a multimeric complex known as an apoptosome, which has a function similar to that of DISC in the extrinsic pathway (Fig. 1). This apoptosome recruits pro-caspase 9 by interacting with its caspase-recruitment domain (CARD) to cause autocatalysis and activation of caspase 9, initiating the caspase signaling cascade. Eventually, effector caspase 3 is activated and apoptosis is induced [22]. The intrinsic apoptotic pathway also initiates caspase-independent apoptosis. Mitochondrial proteins such as $\mathrm{Omi} / \mathrm{HtrA} 2$ and the apoptosis inducing factor (AIF) are able to initiate caspase-independent apoptosis via programmed cell death (PCD) [33]. Whilst caspase-independent mechanisms of PCD remain least well understood, in vitro evidence suggests that targeting these proteins and other caspase-independent signaling like RIPK-3 mediated necroptosis could potentiate cancer cell death and thus supersede the requirement to modulate caspase activity, at least via the intrinsic pathway [33, 34]. However, the mechanisms governing the initiation of necroptosis mediated cell death are so far unexplored in vivo and the repercussions of its potential pro-inflammatory nature have not been fully elucidated [34, 35].

The extrinsic and intrinsic apoptotic pathways induced in response to chemotherapy or radiotherapy indirectly induce caspase-dependent apoptosis in cancer cells. 
Terminal caspases 3 and 7 activate nucleases, cytoplasmic substrates and multiple degradation enzymes to trigger PCD [36]. Importantly, IAPs prohibit the activation of caspase 3 and 7 following activation of extrinsic and intrinsic pathways of apoptosis, alike. Targeting molecules such as IAPs will relieve the inhibitory stress on caspases and encourage unhealthy chemotherapy-resistant cells to undergo cell death via apoptosis.

\section{Inhibitors of apoptosis (IAPs)}

The execution of extrinsic (death receptor) and intrinsic (mitochondrial) apoptotic signals are modulated by a family of structurally distinct IAPs; X-linked (XIAP), cellular (cIAP1, cIAP2), neuronal (NIAP), testis specific (Ts-IAP), Bir-ubiquitin conjugating enzyme (BRUCE), Survivin and Livin. Structurally, IAPs are approximately 70 amino acids long and contain zinc finger Baculovirus IAP Repeat (BIR) domains that are responsible for the inhibitory properties of IAPs as they prevent the conversion of zymogenic procaspases to active caspases [37]. Whilst IAPs are expressed basally, their expression is preferentially upregulated in both disease and drug resistance. For example, significantly higher expression of all IAP family members was reported in a subset of CD133+ glioblastoma stem cells exhibiting resistance to temozolomide, carboplatin and paclitaxel [38]. Notably, the expression of XIAP and cIAP1 was 21.9 and 39.0-fold higher in resistant compared to sensitive cells, respectively [38]. The characteristics of each IAP member, inclusive of alternative names, structure and expression profiles are outlined in Table 1.

Therapeutic modulation of cells overexpressing IAPs can be approached in multiple ways; by down-regulating their expression to potentiate cell death when apoptotic stimuli are present, or via an up-regulation of natural proapoptotic proteins such as Bax, TNF- $\alpha$ or FasL, or by direct inhibition of IAPs action on caspases [92]. Therapeutics that directly antagonize IAPs, or over-express, mimic and increase the potency of pro-apoptotic proteins have been the most widely accessible strategies to date. Dependent on their efficacy, these approaches could work mono-therapeutically or to re-sensitize cancer cells to chemotherapeutic agents by synergizing with them with combinatorial therapies (discussed later, see Table 2).

\section{Modes of direct IAP antagonism}

Studies assessing knockout strategies in cancer cells with high endogenous expression of IAPs have been essential in highlighting their role in the maintenance of resistance to various anti-cancer therapies. For example, shRNA mediated knockdown of XIAP re-sensitized ovarian cancer cells to cisplatin therapy and suppressed tumorigenicity in nude mice via increased apoptosis [113]. Similar findings of reduced tumorigenicity, reduced angiogenesis and improved apoptosis were reported following shRNA mediated knockdown of Survivin in breast and ovarian carcinoma in vivo [114]. In the clinic, phase II trials initially reported successful outcome in acute myeloid leukemia (AML) patients undergoing therapy using antisense oligonucleotide AEG35156 that target XIAP [115, 116]. Despite this initial success and confirmed on-target knockdown [116], a later trial failed to report a similarly improved outcome in patients with advanced pancreatic cancer [117]. Whilst gene silencing is attractive prospect, its potential clinical relevance is limited by lower knockdown efficiency in patient samples, compared to those demonstrated in cell culture [115] and by the transient nature of XIAP repression [117]. Still, strategies for RNAi remain important tools to dissect the mechanistic and functional role of IAPs in cancer.

Primary IAP antagonists are SMAC mimetics. These are synthetic mimics of an endogenous second mitochondriaderived activator of caspase/direct IAP binding protein with low pI (SMAC/DIABLO) protein, a natural inhibitor of IAPs [118, 119]. Endogenous SMAC/DIABLO exerts its inhibitory effect on IAPs by binding to the zinc-binding baculovirus IAP repeat (BIR) domain of X-chromosomelinked IAP (XIAP) [120], competitively inhibiting its binding with effector caspases-9, 3 and 7, thus preventing their inhibition. Therefore, active caspases remain active and PCD can occur. SMAC binding to IAPs is facilitated by the interaction of its $4 \mathrm{~N}$-terminal residues (alanine-valine-phenylalanine-isoleucine) with BIR domains on XIAP [120] (Fig. 2).

SMAC/DIABLO can also bind to BIR domains of cellular IAPs (cIAPs), promoting their ubiquitination and proteasomal degradation. In turn, this can stimulate the production of TNF-alpha which sensitizes the cell to TNFalpha dependent apoptosis, further promoting cell death [121]. Although SMAC/DIABLO targets both cIAP and XIAP, it has a greater affinity for the BIR3 domain of XIAP than for the BIR2 domain of cIAPs [122]. Therefore, antagonist action of SMAC mimetics may be optimal in targeting the BIR3 domain of XIAP. However, it is still unclear if single agent therapy is more effective than combinatorial therapy. Figure 2 schematically outlines the structural characteristics of two highly expressed and prominently targeted IAP proteins in cancer; XIAP and cIAP1/2. It also highlights various modes of therapeutic intervention explored to modulate their actions.

Survivin and BRUCE are other prominent IAPs. Outlined in Table 1 , these are structurally unique owing to only one BIR domain and therefore, are less easily targeted via SMAC mimetics. Survivin and BRUCE are mechanistically 


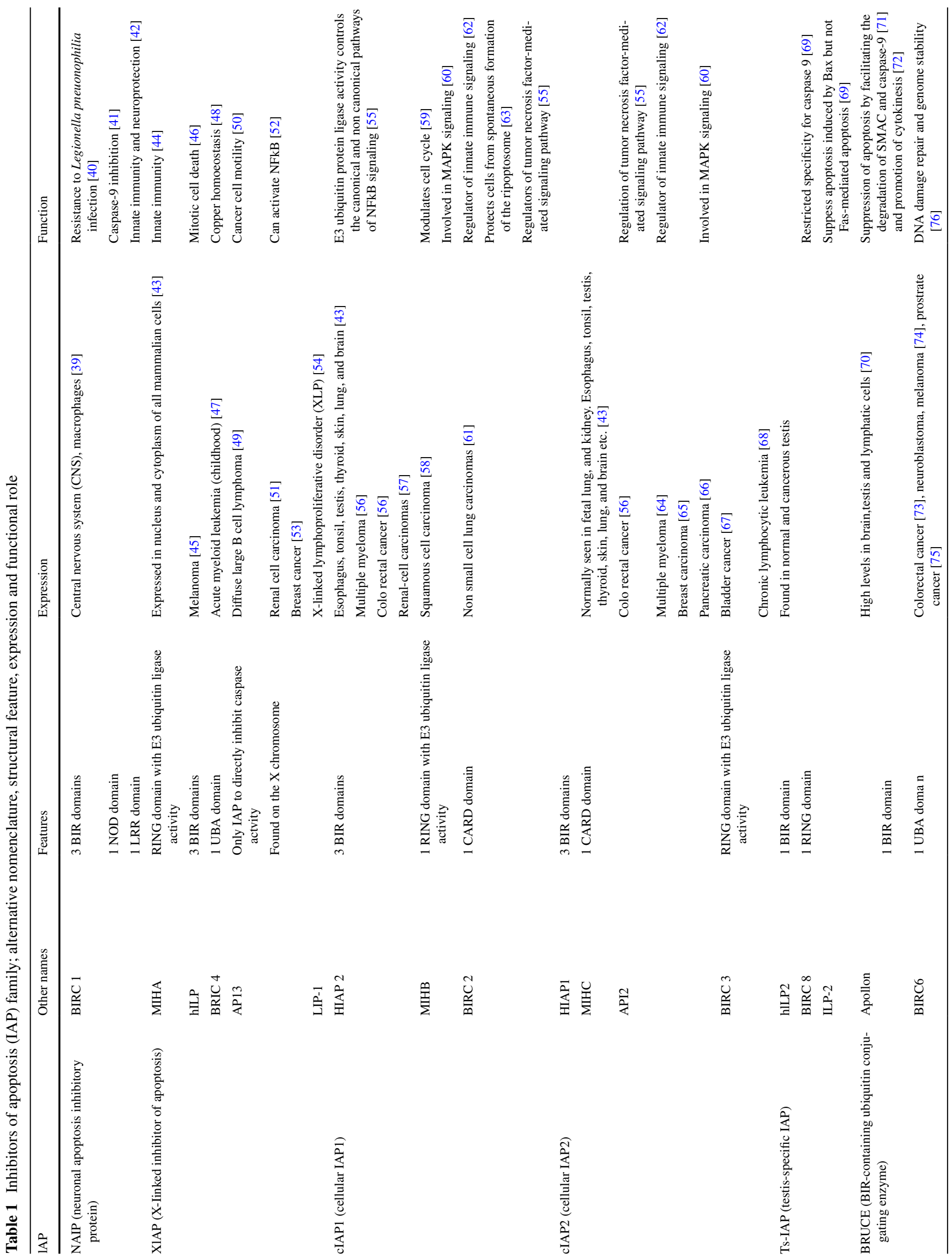




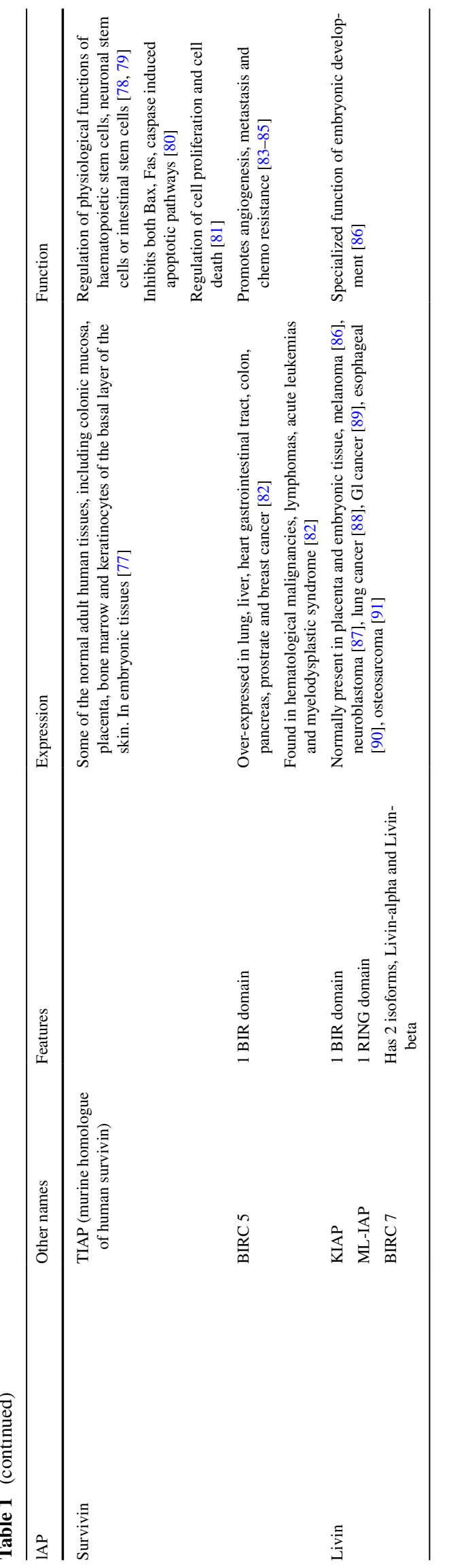

different to other IAPs in that they regulate cytokinesis and multiple mitochondria-mediated signaling pathways, rather than apoptosis (reviewed in [92]). It has been reported that survivin can form a complex with XIAP to improve its stability as an apoptosis suppressor [123] and metastasis promotor [124]. However, it was shown that XIAP antagonist XAF1 can displace survivin to improve tumor cell death [125]. High survivin expression has been reported as the cell's "Achilles heel" in chemoresistance and it has been suggested as a prominent gene to target anti-cancer therapy resistance in neuroblastoma [126, 127]. shRNA mediated knockdown of survivin is an effective strategy to resensitize H292 lung cancer cells to cisplatin therapy [110]. Ardisianone, a natural benzoquinone, demonstrated a timedependent a degradation of survivin and upregulation of cLAP1/2 expression in human refractory prostate cancer (HRPC) cell lines PC-3 and DU-145 following [128]. In a concentration-dependent manner, this molecule inhibited cell proliferation and induced both caspase-dependent and caspase-independent apoptosis via down-regulating $\mathrm{Bcl}-2$ proteins, producing ROS, disrupting the mitochondrial membrane potential and interfering with the PI3K/Akt signaling pathway [128]. Given its ability to upregulate IAP expression, ardisianone might be a promising candidate for acquired chemotherapy- or IAP-antagonist resistance.

\section{Novel SMAC mimetic design}

Whilst endogenous SMAC/DIABLO exerts its actions within micromolar ranges, SMAC mimetics such as AT-406 are more efficacious. This monomeric class of SMAC inhibitors exhibit strong binding affinities with XIAP and cIAP1/2 at nanomolar ranges [93]. To exert supraphysiological effects, researchers are continually working to improve the potency and apoptotic efficiency of novel SMAC mimetics to abolish drug resistance [129]. Reports of improved analogs resulted from the development of a second class of bivalent SMAC mimics that targeted more than one BIR domain region on XIAP, improving the rate of apoptosis [130]. A good example of a successful bivalent SMAC mimetic is 'Birinapant', currently undergoing phase 1 and 2 clinical trial for the treatment of ovarian cancer (Medivir, 2017) (outlined in Table 2).

Alternatively, researchers mutated the AVPI N-terminal sequence of SMAC which binds to the BIR domains of IAPs to IPVA (isoleucine-phenylalanine-valine-alanine) and FPVA (formic acid-phenylalanine-aline-alanine) using predictive computational analysis and induced fit docking models (Gold-score software). By doing so, the L-amino acids were substituted to D-amino acids, stabilizing the hydrophobic interaction of the SMAC mimetic within the IAP binding pocket whilst also preventing proteolytic action via XIAP BIR3 domains [131]. Results 


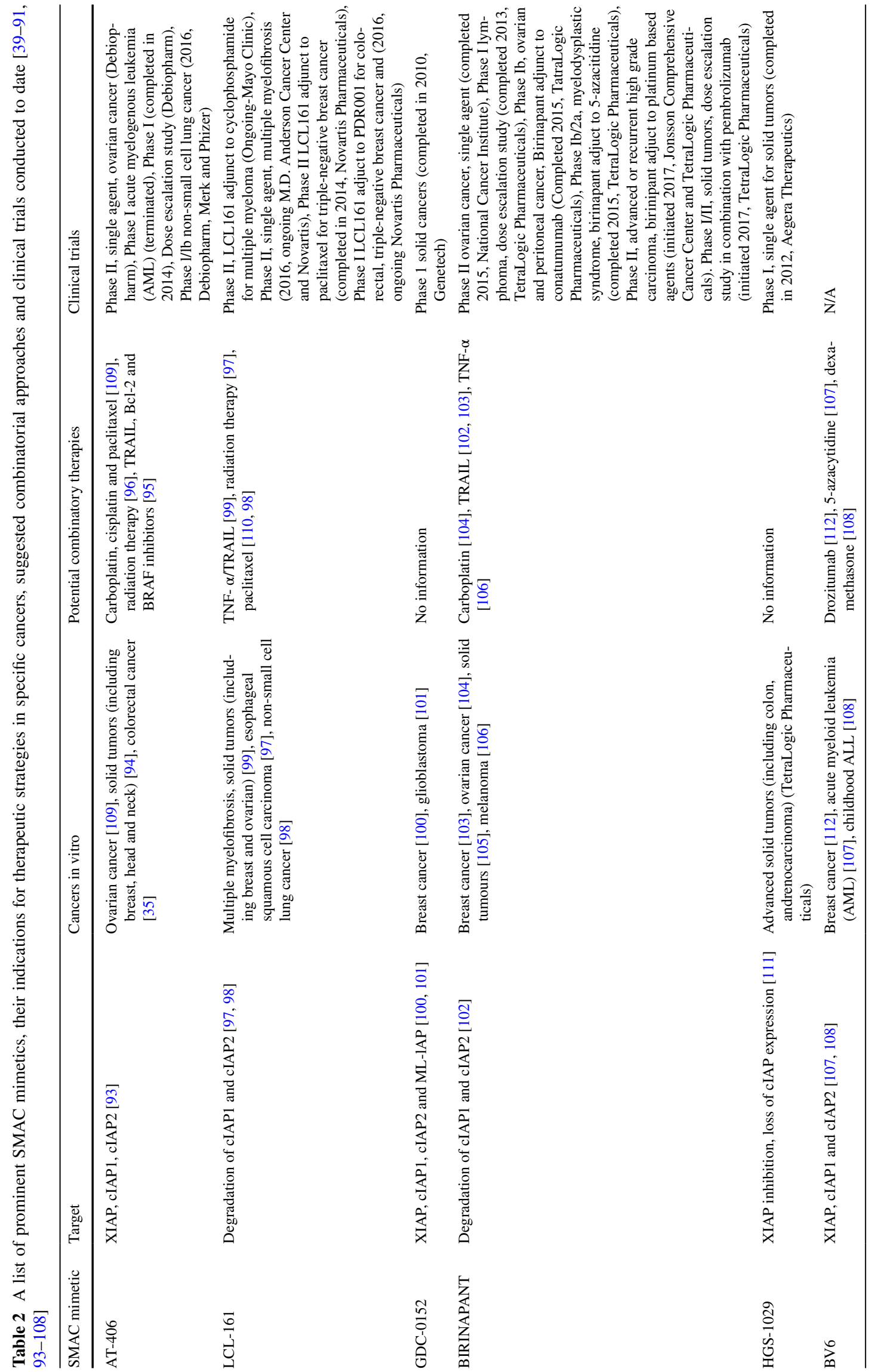


suggested that FPVA and AVPF were able to induce significantly improved apoptosis in L1236 cells and AVPF and AVPI sensitized etoposide resistance in L136 cells [131]. This computational approach provided an accurate predictive model for mutational analysis and as more information regarding SMAC mimetics becomes available, this can be further improved upon in future. Furthermore, the ability to dock inhibitors to the BIR3 domain of XIAP, instead of BIR2, better mimics the endogenous SMAC protein which has a higher affinity for BIR3 than BIR2 [131]. In this manner, apoptosis mediated by the binding between the retroinverse SMAC peptide and the BIR3 domain of XIAP was greatly optimized. Favorably, these authors utilized Hodgkin Lymphoma cell lines L1236 and L428, with high endogenous expression of XIAP [131]. In going forward, it will be useful to assess the efficacy of retro-inverse SMAC peptides in alternative cancer cells types with varying levels of XIAP expression.

\section{Specificity of SMAC mimetics}

As discussed, SMAC peptides that utilize XIAP as an IAP of interest whilst focusing on targeting the BIR3 domain of XIAP are most favorable as direct inhibitors of downstream caspases. XIAP inhibits both the extrinsic and intrinsic apoptotic pathways via direct inhibition of caspases, unlike cIAP1/2 which acts via proteasomal degradation or ubiquitination and may be limited by its initiation of cell protective effects via NF-kB signaling [132]. Critically, XIAP expression is up-regulated in a number of different types of cancers, some of which are intrinsically resistant to chemotherapy. Therefore, XIAP antagonism can be a powerful strategy to overcome chemo-resistance across a variety of cancers and a number of current IAP-antagonist strategies involve XIAP down-regulation or inhibition to promote cancer cell survival. Examples of compounds in development that target XIAP include SM-12d, Compound 21, AT-406 (Ascenta Therapeutics), LCL-161 (Novartis Pharmaceuticals), GDC-0152 (Genentech), GDC-0197 (Genentech), SM-164, Birinapant/ TL32711 (Tetralogic Pharmaceuticals), HGS1029, LBW-242, Compound 10 (Aegera Therapeutics), Compound 24 (Allist Pharmaceuticals) and Compound 1A (Genentech). Table 2 further outlines a list of prominent SMAC mimetics, their targets, cancer treatment profiles and progress in clinical trials.

It is important to note that whilst SMAC/DIABLO has better affinity for BIR3 and thus is a direct inhibitor of caspase 9 activation, the BIR2 domain is responsible for inhibiting terminal caspases 3 and 7 [133]. This research suggests that it could be advantageous to design novel, eqipotent mimetics that can target BIR2, thus facilitating modulation of both the intrinsic and extrinsic apoptotic pathways to amplify its effect. The specificity of various
SMAC mimetics for BIR3 and its subsequent increased potency is outlined in detail in recent a patent review [134]. Some examples of patented potent molecules include the monovalent SMAC mimetic WO2014060767 (Astex Pharmaceuticals) which demonstrated $100 \%$ inhibition of cIAP1 BIR3 activity at concentrations as low as $12 \mathrm{nM}$, and $94 \%$ inhibition of XIAP BIR3 activity at $40 \mathrm{nM}$ [134]. Interestingly, WO2014060767 is one of the few AVPI IAP antagonists without an alanine warhead in the SMAC peptide sequence. This approach is purported to create a more balanced binding affinity between XIAP and cIAP via a slight alteration in H-bond charge affinity that does not interfere too heavily with the conserved backbone of the molecule [135]. Other SMAC mimetic without an alanine warhead include WO2014060768 (Astex Pharmaceuticals) and WO2014060770 (Astex Pharmaceuticals), which are both potent SMAC inhibitors able to inhibit cIAP 1 and XIAP activity at low concentrations via binding at their respective BIR3 domains [134].

An example of a potent monovalent SMAC mimetic selective for cIAP1 BIR3 is Takeda's JP2012176934 Compound 21. This small molecule inhibited $99 \%$ of cIAP1 activity at $3 \mu \mathrm{M}$ whilst also inhibiting the proliferation of a MDA-MB-231 breast cancer cell line by $93 \%$ at concentrations as low as $0.1 \mu \mathrm{M}$ [134]. Although claimed to exhibit substantial steric hindrance, some XIAP BIR2 selective monovalent SMAC mimetics also display extremely high potencies. Examples of these include Roche's WO2014023708 Compound '1d' and WO2014026882 which demonstrate IC50s as low as 0.029 and $0.013 \mu \mathrm{M}$, respectively [134]. Importantly, these molecules might be excellent candidates for combination therapy with anticancer agents, especially given that some are shown to reduce cell proliferation which can slow, or even halt tumor growth. However, their potential to overcome acquired and intrinsic chemotherapy resistance is so far unreported.

Some researchers suggest that the involvement of IAP regulation in bone metastasis and osteoclast differentiation might demonstrate significant clinical implications for patients undergoing IAP antagonist treatment [136]. They discussed the implications of targeting cIAPs and its actions on the alternative NF-kB signaling pathway that promote osteoclastogenesis via NIK stabilization and subsequent activation of differentiation inducing transcription factors such as NFATc1 [136]. These observations followed their study on the use of SMAC mimetic, BV6, in mouse model demonstrating both osteoporosis and increased tumor growth when 4T1 breast cancer cells were injected into the tibia [137]. Importantly, this tumorigenesis was limited to the bone-microenvironment and could be overcome by combining IAP antagonists with the antiresorptive drug, zoledronic acid [137]. Given that recent in vitro data reveals BV6 as a promising and effective single or 


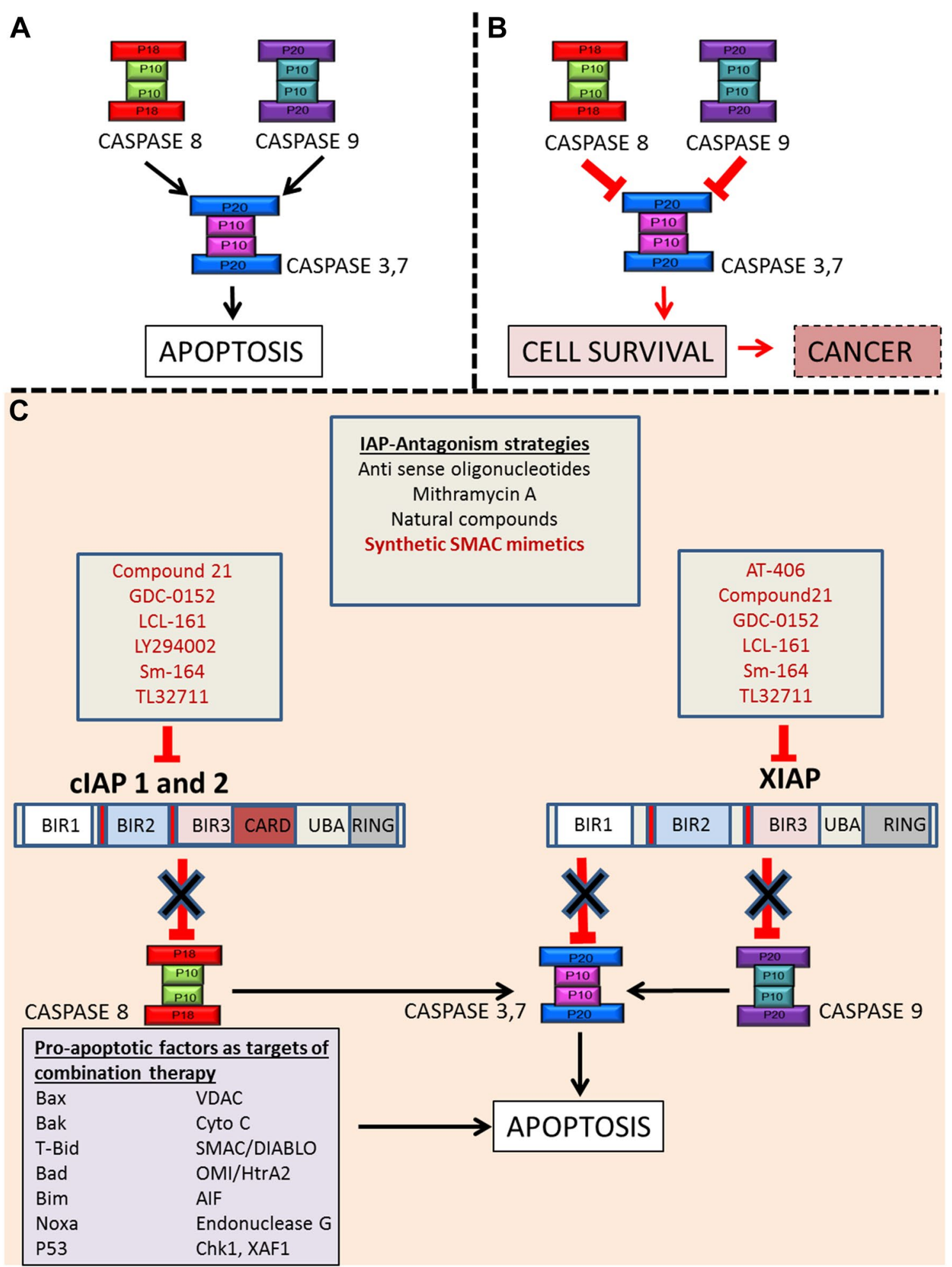

Fig. 2 Downstream apoptotic pathways decide cell fate. In physiological conditions, IAPs mediate cell and tissue homeostasis by mediating apoptosis. a In normal conditions, caspases are uninhibited and the cell under goes apoptosis and $\mathbf{b}$ In cancer pathology, the cell escapes apoptosis and proceeds to tumor formation. IAPs are endogenous proteins that inactivate caspases via direct binding, preventing apoptosis thus contributing to oncogenesis and resistance to therapy. c Strategies to target IAPs for anti-cancer therapy include RNA knockdown, small molecule inhibitors and SMAC mimetics. SMAC mimetics are listed by their affinity for either XIAP or cIAP $1 / 2$ (RED). Also highlighted are various pro-apoptotic factors, often used as parameters, and targets, of successful combinatory therapies that promote apoptosis 
combinatory therapeutic agent in re-sensitizing acute lymphoblastic leukemia (ALL) cells to chemotherapies [138], more information on the efficacy of SMAC mimetic in in vivo settings will be essential as this field progresses.

\section{SMAC mimetic resistance}

Despite the fact that SMAC mimetics are designed to mimic their endogenous counterparts, albeit with improved potency, there are some cell types that exhibit intrinsic resistance to these synthetic compounds-often alongside resistance to chemotherapeutic agents.

An example of this phenomenon includes chronic lymphocytic leukemia (CLL) cells that are especially resistant to SMAC mimetics targeting cIAP1/cIAP2 activity [139]. It is understood that their resistance to SMAC mimetics, and possibly to chemotherapeutic agents, may be attributed to an elevation in aberrant NF-kB activity in ripoptosome-lacking CLL cells [139]. In cells lines sensitive to cIAP1/2 antagonizing SMAC mimetics, resistance to chemotherapy drugs can be overcome by TNF- $\alpha$-mediated apoptosis following ripoptosome formation [140]. As the SMAC mimetic antagonizes, ubiquitylates and degrades cIAP1/2, a ripoptosome complex is formed via the assemblage of RIPK1 (receptor-interacting serine/threonine-protein kinase 1), FADD (Fas-associated protein with death domain), FLICE-like inhibitory protein and caspase-8, and can initiate autocatalysis and activation of caspase-8, which, in turn results in a sensitization to TNF- $\alpha$-dependent apoptotic cell death [141]. However, resistant-CLL cells are unable to associate with one another to form a riptosome complex, despite degradation of cIAP $1 / 2$ by SMAC mimetic to induce TNF- $\alpha$ production and the presence of RIPK1, FADD, FLICE-like inhibitory protein and caspase-8 [139]. In this case, caspase- 8 activation is reduced and the apoptosis-inducing caspase-cascade is minimized, rendering CLL cells resistant to SMAC mimetics.

Studies have reported that prolonged exposure $(>3 \mathrm{~h})$ of cancer cells to SMAC mimetic treatment results in increased expression levels of cIAP2 in CLL cells [139], lung carcinoma cells [140], colon carcinoma and melanoma carcinoma cells [142]. It was hypothesized that an increase in cIAP2 may be required for maintenance of resistance in these cell lines and therefore, this was more closely examined via PI3K inhibitor LY294002, known to suppress cIAP2 expression [139]. Whilst SMAC mimetic sensitivity was restored in lung carcinoma cells [140], it did not yield similar results in CLL cells [139]. These results suggest that targeting PI3K and NF-kB may be more useful in some cancer cell types than others, and that other factors modulating cIAP expression may be of relevance to the development and maintenance of SMAC mimetic resistance in CLL cells. Although it is clear that CLL cells do not respond to cIAP specific SMAC mimetics such as Compound A [139], the BIR3 specific SMAC mimetic (i.e. XIAP targeted) Smac066 improves sensitivity in CLL cells [143].

Of note, the implications of targeting cIAP $1 / 2$ mediated cell death in hematopoietic malignancies, such as CLL, remain controversial. Authors Lau and Pratt proposed that the effect of cIAPs on a cells physiological state is largely context-dependent, suggesting that whilst targeting cIAPs largely suppress tumorigenesis via their classical signaling action on caspases, the subsequent ubiquitination of cIAP can lead to constitutive NF-kB signaling, NIK ubiquitination, cell proliferation and tumor progression via a downregulation in pro-apoptotic p53 signaling [132]. Others suggest that cIAP targeting may have positive therapeutic synergy with cancer vaccines following a rapid sensitization to TNF- $\alpha$ signaling [144]. It will be important to consider targeting alternative pathways to address resistance to cIAP targeted SMAC mimetics in going forward. These might include further research into TNF- $\alpha$ mediated caspase-independent necroptosis, reported in apoptotic resistant cells lacking both FADD and caspase-8 expression that were stimulated and re-sensitized with the bivalent SMAC mimetic BV6 [145].

\section{Combinatory therapies to overcome resistance}

\section{IAP antagonism and chemotherapy resistance}

In recent years, in vitro studies have demonstrated that SMAC mimetics, in combination with anticancer drugs and TRAIL (TNF-related apoptosis-inducing ligand) can effectively enhance apoptosis and cell death in numerous cancer cell types, including T98G glioblastoma cells [146], HeLa cells [147] and lung adenocarcinomas [148]. Early research suggested that SMAC mimetics could enhance the sensitivity of anticancer agents' paclitaxel, etoposide and doxorubicin in MCF-7 breast cancer cells [149]. Subsequently, researchers continued to investigate novel analogs of SMAC mimetics, revealing that SMAC mimetic also sensitized breast cancer cells to TRAIL-induced apoptosis treatment [150]. These results showed that growth was suppressed but apoptosis was not induced in some cell lines, such as T47D and MDA-MB-453, questioning their relevance to apoptosis-related cell death pathways [150].

Promising results have been shown for AT-406, an oral SMAC mimetic, in the sensitization of platinum based chemotherapy drugs such as carboplatin, cisplatin and paclitaxel in ovarian cancer cells [109]. Whilst AT-406 was an effective single agent for the treatment of OVCAR8, SKOV-3, and OVCAR-3ip carboplatin-resistant ovarian cancer, the most promising results indicated sensitization 
to platinum resistant phenotypes in vitro and in vivo [109]. Induction of AT-406 mediated apoptosis in chemoresistance is understood to occur via downregulated expression of cellular XIAP, whereas cIAP1/2 degradation occurs in both sensitive and resistant cell lines [109]. XIAP dysregulation highlights AT-406 as an attractive SMAC mimetic, given that XIAP is an inhibitor of both intrinsic and extrinsic apoptotic pathways. Targeting both expression and inhibition via one compound truly maximizes its potential as an antagonist of IAPs. Refer to Table 2 for a clinical profile of AT-406.

Research to compare the effectiveness of SMAC mimetic analogs across differential cancer cell types are currently lacking. Bockbrader and colleagues demonstrated similar responses across multiple breast cancer cell types, and this is promising for broad spectrum breast cancer treatment [150]. However, future studies encompassing SMAC mimetic treatment across various cancer cell types will be essential. Within the last 5 years, potential therapeutic indications for small molecule inhibitor FL118 understood to act via inhibition of survivin, XIAP, cIAPs and Mcl-1 was reported [151]. This study demonstrated superior anti-tumorigenic activity in colon, lung, breast and prostate cancer cells exhibiting resistance to a range of first line chemotherapies. Moreover, these findings were replicated in a mouse model of head and neck cancer [151]. Researchers have now begun to investigate clinically compatible formulations of FL188, improving its toxicity and bioavailability [152].

In some instances, the discussed therapies may be ineffective as single-agents. When this occurs, combinatorial treatments should be explored. For example, the orally active SMAC mimetic LCL161 has been demonstrated to synergize with paclitaxel to restore chemosensitivity in hepatocellular carcinoma cells (HCCs) [110]. Other studies have demonstrated that the effectiveness of LCL161 was dependent on a low level of Bcl-2 protein expression in HCC cells [153]. However, despite relatively low Bcl-2 expression, hepatocellular carcinoma cell lines SNU423 and $\mathrm{HuH} 7$ were both intrinsically resistant to LCL161 [110]. This suggests that there may be more mechanisms contributing to SMAC resistance in hepatocellular carcinoma. This is currently unclear and research into alternative SMAC mimetic resistant cell types is needed. Even in combination with paclitaxel, apoptosis via LCL161 was induced with markedly low potency in SNU423 and $\mathrm{HuH7}$ cells $(>100 \mu \mathrm{M})$, [110]. Interestingly, as apoptosis increased, a decrease in cell proliferation was also reported, but XIAP and cIAP1/2 levels were unchanged. This might suggest that whilst combinatorial treatment enhanced the anti-proliferative effects in HCC cells, the pro-apoptotic effects may not solely be a result of IAP inhibition [110]. Of most concern, a recent study reported of a lymphoma mouse model that exhibited accelerated disease growth following treatment with LCL161, suggesting major contraindications for cLAP1/2 targeting via LCL161 in lymphoma [154]. In these instances, it is important to question the clinical relevance of SMAC mimetics targeting cIAPs for caspase-mediated apoptosis, given their potential to garner off-target effects via NF-kB signaling. Despite these concerns, several ongoing clinical trials are currently exploring LCL161 as a single and combinatory agent in the treatment of various cancers (Table 2).

\section{TRAIL resistance}

TNF-related apoptosis-inducing ligand (TRAIL) binds to death receptors DR4 (TRAILRI) and DR5 (TRAILRII) on the cell membrane to induce apoptosis in cancer cells (refer to Fig. 1 for more detail on the cellular mechanism of TRAIL-induced apoptosis). When TRAIL associates with its receptor, there is a caspase- 8 mediated cleavage of Bid, which becomes truncated-Bid (t-Bid) and promotes the activation of Bax [155]. This provides cross-talk between the extrinsic and intrinsic pathways, known as the mitochondrial amplification loop $[15,16]$. Subsequently, mitochondrial PTPs release cytochrome $\mathrm{c}$ and the apoptosome is formed after aggregation of cytochrome c, pro-caspase- 9 , dATP and Apaf- 1 . This apoptotic caspase-cascade is initiated via the intrinsic apoptotic pathway [155].

Cells that respond to TRAIL signaling are categorized into two types; 'type 2' cells, such as hepatocytes and HCT-116 cells, require mitochondrial amplification (via intrinsic pathway) of the TRAIL death signal and 'type 1' cells, such as thymocytes, do not [156, 157]. Importantly, type 2 cells can become resistant to TRAIL therapy if anti-apoptotic members of the intrinsic apoptosis pathway, like Bcl-2, become dysregulated [158].

Cancer cells are reported to highly express TRAIL receptors, specifically DR4 and DR5, while healthy cells merely express 'decoy' receptors DcR1 and DcR2 [156]. Thus, TRAIL-induced apoptosis is an attractive way to combat cancer since it is highly specific for cancer cells and takes advantage of the patient's immune cells, which also highly express these receptors [159]. Importantly, this minimizes cytotoxicity to normal, healthy tissue. Regardless of the immuno-modulatory function and specificity of TRAIL-therapy, many cancer cells are resistant to TRAIL following inadequate signal amplification via the intrinsic apoptosis pathway. A primary example of TRAIL resistance exists in 'type 2' colon cancer cells HCT-116 harboring a deficiency in Bax [160]. 


\section{IAP antagonism to overcome TRAIL resistance}

The importance of XIAP antagonism in cancer treatment is additionally demonstrated by its ability to overcome TRAIL resistance. XIAP is responsible for the inhibition of effector caspases-3/7 via proximity induced proteasomal degradation at their active sites (Fig. 1) [161]. To sensitize 'type 2' cells to TRAIL therapy researchers have investigated the merits of repressing XIAP activity via SMAC mimetics [162], shRNA knockdown [162, 163] and Mithramycin A [164] -all with good success. Results demonstrate that SMAC mimetic, Sm-164 (a duel target of XIAP and cIAPs with a higher affinity for XIAP), was 1000 -fold more potent in inducing apoptosis and restoring sensitivity to TRAIL than a cIAP specific SMAC mimetic [130]. Additionally, TRAIL-resistant prostate cancer cells expressed excessive amounts of XIAP and cIAP and exhibited improved TRAIL sensitivity when XIAP expression was knocked down [162]. Data supporting the involvement of XIAP in TRAIL resistance suggests that neutralizing XIAP might be critical for TRAIL sensitivity and an attractive target for potential combinatory therapy in the treatment of 'type 2' cancer cells. Additionally, XIAP also protects healthy 'type 2' cells from uncontrolled cell death. It has been suggested that broadly antagonizing XIAP as a sensitization strategy could lead to healthy hepatocyte death and subsequent liver damage [165].

\section{TRAIL receptors in TRAIL resistance}

In addition to XIAP over-expression, insufficient expression of TRAIL receptors also contributes TRAIL resistance in many cancers, including in acute lymphoblastic leukemia cells (ALL). ALL cells demonstrate significantly altered cell-surface expression of DR4 in TRAIL resistance. Here, authors suggested that dysregulated receptor trafficking and increased receptor glycosylation may be of importance to TRAIL sensitivity [166]. Other conditions that hamper apoptosis include mutations in the death domain of TRAIL receptors or in the ligand binding pocket [167], and high expression of decoy antagonistic receptors [168]. The apoptotic potential of TRAIL has shown to improve via combinatory treatment with etoposide, doxorubicin or paclitaxel mediated upregulation of both DR4 (TRAILI) and DR5 (TRAILII) expression in numerous breast cancer cells types in vitro, as well as in tumorigenic mice [169]. The anti-tumor antibiotic Bleomycin and the histone deacetylase inhibitor MS-275 have also upregulate DR4 and DR5 to sensitize cancer cells to TRAIL-induced apoptosis [170, 171]. Lastly, microtubulin targeting compound PBOX-15 (pyrrolo-1,5-benzoxazepine) treatment in myeloma in Jurkat ALL cells also resulted in an upregulation of DR5 to enhance TRAIL-induced apoptosis [172].

\section{Bcl-2 expression in TRAIL resistance}

Relating specifically to activation of the intrinsic apoptotic pathway, HCT-116 wild type cells demonstrated a sensitization to apoptosis when Mcl-1 was inhibited. Mcl-1 selectively inhibits Bax/Bak signaling, preventing crosstalk between the death receptor pathway and the intrinsic apoptotic pathway [26]. Improved sensitivity to TRAIL was reported following release of endogenous SMAC when Mcl-1 was found to be overexpressed [173]. This might highlight further therapeutic implications for 'pan' inhibitor FL118 targeting both XIAP and Mcl-1, alongside survivin and cIAP1/2 [151]. Interestingly, it was recently shown that Bax activation is Mcl-1 independent in some cell types (including HCT-116 cells), rendering its inhibition an ineffective single agent treatment [174].

Sensitivity to TRAIL resistance is further demonstrated by upregulated expression of pro-apoptotic agents as Bax/ Bak. In 2011, increased Bax expression and subsequent improved sensitivity to TRAIL was reported in colon cancer cells following exposure to the plant derived compound Nimbolide [175], although it is important to note that this article has since been retracted by the publisher. Other research suggests that Nimbolide exerts its anti-tumorigenic effects via a downregulation in cell proliferation and metastasis [176]. Whilst these strategies promote apoptotic cell death, they do not appear to be effective in switching 'type 2' cells to mitochondrial pathway independent 'type 1 ' cells.

Other than XIAP repression, Mcl-1 inhibition and proteasome inhibition, resistance to TRAIL may be overcome by either kinase inhibitors or BH3 mimetics. Kinase inhibitors such as Roscovitine and Sorafenib (approved for HCC treatment) suppress activation of Mcl-1 [177], downregulate expression of c-FLIP [178], and aid in DISC-pro-caspase- 8 activation to facilitate apoptosis [179]. In a similar fashion, BH3 mimetic ABT-737 represses pro-survival Bcl-2 proteins, such as Mcl-1, to further exert a pro-apoptotic effect via Bax/Bak signaling in chemoresistance [180]. However, ABT-737 is Bax/Bak dependent and would not be effective in double deficient HCT-116 cells, or Mcl-1 independent cells [174].

For Bax-/Bax-deficient HCT-116 cells, proteasome inhibitors MG132 and Bortezomib (BZM) sensitized TRAIL resistance in HCT-116 Bax-/Bak-double deficient cells [181]. Some TRAIL-resistant cancer cells are neither Bax/Bak deficient, nor do they have abnormally low expression of DR4 and DR5. Herein, protein analysis revealed high levels of c-FLIP, anti-apoptotic Bcl-2 members and IAPs [182]. It is likely that c-FLIP (cellular FLICE inhibitory protein), Mcl-1 and IAPs such as XIAP and cIAP all contribute to TRAIL resistance. c-FLIP tends to promote TRAIL-resistance in malignant 
cancer cells by preventing the formation of DISC [183]. TRAIL resistance was improved via siRNA knockdown or drug induced downregulation of c-FLIP via rocaglamide combined with SMAC mimetic AT406 [182]. Enhanced TRAIL-induced apoptosis was previously demonstrated using the flavonoid kurarinone by downregulating cFLIP in HeLa cells [184].

\section{IAPs and antibody-based therapy resistance}

Drozitumab is a human monoclonal antibody that binds specifically to TRAIL receptor DR5 on cancer cells to induce apoptosis [185]. Most breast cancer cells, including the basal-like MDA-MB-231-TXSA cells, are extremely sensitive to drozitumab-induced apoptosis, but prolonged exposure can induce acquired resistance to the cytotoxic agent [186]. There is no correlation between sensitivity to Drozitumab and expression of DR4/5 in cancer cells, unlike in TRAIL resistant cells. However, like TRAIL resistant cells, these resistance-causing factors may, in part, be mediated by IAPs. Demonstrating this, the pan IAP antagonist SMAC mimetic BV6 used in combination with Drozitumab restored its sensitivity and completely inhibited the growth of MDA-MB-TXSA tumors in a mouse model [112]. Interestingly, this drug combination was independent of TNF- $\alpha$ and was successful in the direct activation of effector caspase- 3 and -7 , suggestive of XIAP antagonism [112]. Moreover, this combination bypassed activation of the mitochondrial amplification loop, commonly required in overcoming TRAIL receptor related resistance [112].

The chemotherapeutic agent doxorubicin has also been reported as an effective sensitizer to Drozitumab via suppressive IAP expression, as well as increased cell-surface expression of DR5 [186]. This also improved sensitivity in vivo whereby inhibited tumor growth, delayed tumor progression and improved chances of survival were reported in mice treated with both doxorubicin and Drozitumab [186]. Given that part of its improved sensitivity was via differential expression of DR5, it could be suggested that this combination might exhibit less toxicity in healthy cells that do not normally express this receptor. Interestingly, Drozitumab-resistant cells also demonstrated sensitivity to taxol, etoposide, cisplatin, and the deacetylase inhibitor, SAHA [186]. Unsurprisingly, patients with acquired resistance to TRAIL are also reportedly cross-resistant to drozitumab-induced apoptosis and the authors suggest potential benefits for patients with drozitumab resistance that switch to TRAIL therapy or explore combination therapies [186].

\section{Conclusion}

Our dependency upon a core group of chemotherapeutics as first line treatment is continually reflected by the generation of acquired chemoresistance across all cancer types. The ever-growing burden of resistance highlights the requirement for a more diverse set of therapeutics in cancer treatment. Though the development of resistance to anticancer agents involves multiple differential pathways, often dependent on drug and tissue type, they share commonality in an overall reduction in cancer cell death. Apoptosis is the primary mediator of chemotherapy mediated cell death and its regulation is not unaffected in the development of resistance. In this review, we have discussed the recent advances in research toward targeting apoptotic pathways in cancer treatment and resistance, with a central focus on the modulation of IAPs. Whilst various combinatorial therapeutic approaches for use of antagonists of IAPs following the development of resistance to chemotherapy, antibody-based therapy and TRAIL resistance were discussed [150, 151, 185], we also focused upon resistance to IAP antagonism itself which may have future implications in the clinic [139, 141].

Research characterizing the expression and regulation of IAPs in disease has facilitated the identification of novel therapeutic options within this field, particularly in relation to the expression and inhibition of XIAP and cIAP1 and 2 [14]. The use of SMAC mimetics as means to exploit IAP overexpression has advantages for specific tumor types [187].

Although original research and clinical studies suggest that IAPs may be effective as single agents in cancer, ongoing clinical studies mostly assess the usefulness of IAP antagonists in combination with alternative cancer treatments to re-sensitize chemotherapy in relapsed cancers [188]. As research progresses, improvements in their therapeutic design may enhance their affinity and specificity for IAP mediated cell death.

This review also highlights the implications for treatment in relation to the development of acquired resistance to IAP antagonists and, indeed, intrinsic resistance that is demonstrated in CLL cell types [139, 143]. These potential limitations warrant scientific discussion to devise strategies for overcoming resistance to IAP antagonism before they become an issue in the clinic. In regards to sensitizing cells to IAP-antagonists, or augmenting the cytotoxic activity of other agents, a wealth of scientific data is available to suggest combinatorial treatments offer the most practical solution.

Funding This study was supported by NPRP grant \# 6-089-3021 from the Qatar National Research Fund (a member of Qatar 
Foundation). The statements made herein are solely the responsibility of the authors.

Open Access This article is distributed under the terms of the Creative Commons Attribution 4.0 International License (http:// creativecommons.org/licenses/by/4.0/), which permits unrestricted use, distribution, and reproduction in any medium, provided you give appropriate credit to the original author(s) and the source, provide a link to the Creative Commons license, and indicate if changes were made.

\section{References}

1. Danial NN, Korsmeyer SJ (2004) Cell death: critical control points. Cell 116(2):205-219

2. Ghobrial IM, Witzig TE, Adjei AA (2005) Targeting apoptosis pathways in cancer therapy. CA Cancer J Clin 55(3):178-194

3. Pouyssegur J, Dayan F, Mazure NM (2006) Hypoxia signalling in cancer and approaches to enforce tumour regression. Nature 441(7092):437-443. doi:10.1038/nature04871

4. Senan S, Brade A, Wang LH, Vansteenkiste J, Dakhil S, Biesma B, Martinez Aguillo M, Aerts J, Govindan R, Rubio-Viqueira B, Lewanski C, Gandara D, Choy H, Mok T, Hossain A, Iscoe N, Treat J, Koustenis A, San Antonio B, Chouaki N, Vokes E (2016) PROCLAIM: randomized phase III trial of pemetrexedcisplatin or etoposide-cisplatin plus thoracic radiation therapy followed by consolidation chemotherapy in locally advanced nonsquamous non-small-cell lung cancer. J Clin Oncol 34(9):953-962. doi:10.1200/JCO.2015.64.8824

5. Sears CR, Cooney SA, Chin-Sinex H, Mendonca MS, Turchi JJ (2016) DNA damage response (DDR) pathway engagement in cisplatin radiosensitization of non-small cell lung cancer. DNA Repair 40:35-46. doi:10.1016/j.dnarep.2016.02.004

6. Su Z, Yang Z, Xie L, DeWitt JP, Chen Y (2016) Cancer therapy in the necroptosis era. Cell Death Differ 23(5):748-756. doi:10.1038/cdd.2016.8

7. Patch AM, Christie EL, Etemadmoghadam D, Garsed DW, George J, Fereday S, Nones K, Cowin P, Alsop K, Bailey PJ, Kassahn KS, Newell F, Quinn MC, Kazakoff S, Quek K, Wilhelm-Benartzi C, Curry E, Leong HS, Australian Ovarian Cancer Study Group, Hamilton A, Mileshkin L, Au-Yeung G, Kennedy C, Hung J, Chiew YE, Harnett P, Friedlander M, Quinn M, Pyman J, Cordner S, O'Brien P, Leditschke J, Young G, Strachan K, Waring P, Azar W, Mitchell C, Traficante N, Hendley J, Thorne H, Shackleton M, Miller DK, Arnau GM, Tothill RW, Holloway TP, Semple T, Harliwong I, Nourse C, Nourbakhsh E, Manning S, Idrisoglu S, Bruxner TJ, Christ AN, Poudel B, Holmes O, Anderson M, Leonard C, Lonie A, Hall N, Wood S, Taylor DF, Xu Q, Fink JL, Waddell N, Drapkin R, Stronach E, Gabra H, Brown R, Jewell A, Nagaraj SH, Markham E, Wilson PJ, Ellul J, McNally O, Doyle MA, Vedururu R, Stewart C, Lengyel E, Pearson JV, Waddell N, deFazio A, Grimmond SM, Bowtell DD (2015) Whole-genome characterization of chemoresistant ovarian cancer. Nature 521(7553):489-494. doi:10.1038/nature 14410

8. Coley HM (2010) Overcoming multidrug resistance in cancer: clinical studies of p-glycoprotein inhibitors. Methods in molecular biology 596:341-358. doi:10.1007/978-1-60761-416-6_15

9. Hersey P, Zhang XD (2003) Overcoming resistance of cancer cells to apoptosis. J Cell Physiol 196(1):9-18. doi:10.1002/ jcp. 10256

10. Zhao Y, Foster NR, Meyers JP, Thomas SP, Northfelt DW, Rowland KM Jr, Mattar BI, Johnson DB, Molina JR,
Mandrekar SJ, Schild SE, Bearden JD 3rd, Aubry MC, Adjei AA (2015) A phase I/II study of bortezomib in combination with paclitaxel, carboplatin, and concurrent thoracic radiation therapy for non-small-cell lung cancer: North Central Cancer Treatment Group (NCCTG)-N0321. J Thorac Oncol 10(1):172-180. doi:10.1097/JTO.0000000000000383

11. Hunter AM, LaCasse EC, Korneluk RG (2007) The inhibitors of apoptosis (IAPs) as cancer targets. Apoptosis 12(9):15431568. doi:10.1007/s10495-007-0087-3

12. Kastan MB, Bartek J (2004) Cell-cycle checkpoints and cancer. Nature 432(7015):316-323. doi:10.1038/nature03097

13. Stojanovska V, Sakkal S, Nurgali K (2015) Platinumbased chemotherapy: gastrointestinal immunomodulation and enteric nervous system toxicity. Am J Physiol Gastrointest Liver Physiol 308(4):G223-G232. doi:10.1152/ ajpgi.00212.2014

14. Augello C, Caruso L, Maggioni M, Donadon M, Montorsi M, Santambrogio R, Torzilli G, Vaira V, Pellegrini C, Roncalli M, Coggi G, Bosari S (2009) Inhibitors of apoptosis proteins (IAPs) expression and their prognostic significance in hepatocellular carcinoma. BMC Cancer 9:125. doi:10.1186/1471-2407-9-125

15. Fulda S (2014) Molecular pathways: targeting death receptors and smac mimetics. Clin Cancer Res 20(15):3915-3920. doi:10.1158/1078-0432.CCR-13-2376

16. Fulda S, Debatin KM (2006) Extrinsic versus intrinsic apoptosis pathways in anticancer chemotherapy. Oncogene 25(34):47984811. doi:10.1038/sj.onc. 1209608

17. Brentnall M, Rodriguez-Menocal L, De Guevara RL, Cepero E, Boise LH (2013) Caspase-9, caspase-3 and caspase-7 have distinct roles during intrinsic apoptosis. BMC Cell Biol 14:32. doi:10.1186/1471-2121-14-32

18. Luthi AU, Martin SJ (2007) The CASBAH: a searchable database of caspase substrates. Cell Death Differ 14:641-650

19. Lavrik I, Golks A, Krammer PH (2005) Death receptor signaling. J Cell Sci 118(Pt 2):265-267. doi:10.1242/jcs.01610

20. Suzuki A, Obata S, Hayashida M, Kawano H, Nakano T, Shiraki K (2001) SADS: a new component of Fas-DISC is the accelerator for cell death signaling and is downregulated in patients with colon carcinoma. Nat Med 7(1):88-93. doi:10.1038/83401

21. Yin XM, Wang K, Gross A, Zhao Y, Zinkel S, Klocke B, Roth KA, Korsmeyer SJ (1999) Bid-deficient mice are resistant to Fas-induced hepatocellular apoptosis. Nature 400(6747):886891. doi:10.1038/23730

22. Lopez J, Tait SW (2015) Mitochondrial apoptosis: killing cancer using the enemy within. Br J Cancer 112(6):957-962. doi:10.1038/bjc.2015.85

23. Real PJ, Sierra A, De Juan A, Segovia JC, Lopez-Vega JM, Fernandez-Luna JL (2002) Resistance to chemotherapy via Stat3-dependent overexpression of Bcl-2 in metastatic breast cancer cells. Oncogene 21(50):7611-7618. doi:10.1038/ sj.onc. 1206004

24. Volkmann N, Marassi FM, Newmeyer DD, Hanein D (2014) The rheostat in the membrane: BCL-2 family proteins and apoptosis. Cell Death Differ 21(2):206-215. doi:10.1038/ cdd.2013.153

25. Waterhouse NJ, Goldstein JC, von Ahsen O, Schuler M, Newmeyer DD, Green DR (2001) Cytochrome c maintains mitochondrial transmembrane potential and ATP generation after outer mitochondrial membrane permeabilization during the apoptotic process. J Cell Biol 153(2):319-328

26. Shamas-Din A, Kale J, Leber B, Andrews DW (2013) Mechanisms of action of Bcl-2 family proteins. Cold Spring Harbor Perspect Biol 5(4):a008714. doi:10.1101/cshperspect.a008714

27. Petros AM, Olejniczak ET, Fesik SW (2004) Structural biology of the Bcl-2 family of proteins. Biochim Biophys Acta 1644(23):83-94. doi:10.1016/j.bbamcr.2003.08.012 
28. Khaled AR, Kim K, Hofmeister R, Muegge K, Durum SK (1999) Withdrawal of IL-7 induces Bax translocation from cytosol to mitochondria through a rise in intracellular $\mathrm{pH}$. Proc Natl Acad Sci USA 96(25):14476-14481

29. Westphal D, Dewson G, Czabotar PE, Kluck RM (2011) Molecular biology of Bax and Bak activation and action. Biochim Biophys Acta 1813(4):521-531. doi:10.1016/j.bbamcr.2010.12.019

30. Lovell JF, Billen LP, Bindner S, Shamas-Din A, Fradin C, Leber B, Andrews DW (2008) Membrane binding by tBid initiates an ordered series of events culminating in membrane permeabilization by Bax. Cell 135(6):1074-1084. doi:10.1016/j. cell.2008.11.010

31. Shoshan-Barmatz V, Ben-Hail D, Admoni L, Krelin Y, Tripathi SS (2015) The mitochondrial voltage-dependent anion channel 1 in tumor cells. Biochim Biophys Acta 1848(10 Pt B):25472575. doi:10.1016/j.bbamem.2014.10.040

32. Lauterwasser J, Todt F, Zerbes RM, Nguyen TN, Craigen W, Lazarou M, van der Laan M, Edlich F (2016) The porin VDAC2 is the mitochondrial platform for Bax retrotranslocation. Sci Rep 6:32994. doi:10.1038/srep32994

33. Mathiasen IS, Jaattela M (2002) Triggering caspase-independent cell death to combat cancer. Trends Mol Med 8(5):212-220

34. Tait SW, Ichim G, Green DR (2014) Die another way-nonapoptotic mechanisms of cell death. J Cell Sci 127:2135-2144

35. Su Z, Yang Z, Xie L, Dewitt JP, Chen Y (2016) Cancer therapy in the necroptosis era. Cell Death Differ 23:748-756

36. Elmore S (2007) Apoptosis: a review of programmed cell death. Toxicol Pathol 35(4):495-516. doi:10.1080/01926230701320337

37. Huang Y, Park YC, Rich RL, Segal D, Myszka DG, Wu H (2001) Structural basis of caspase inhibition by XIAP: differential roles of the linker versus the BIR domain. Cell 104(5):781-790

38. Liu G, Yuan X, Zeng Z, Tunici P, Ng H, Abdulkadir IR, Lu L, Irvin D, Black KL, Yu JS (2006) Analysis of gene expression and chemoresistance of CD133+ cancer stem cells in glioblastoma. Mol Cancer 5:67. doi:10.1186/1476-4598-5-67

39. Maier JK, Balabanian S, Coffill CR, Stewart A, Pelletier L, Franks DJ, Gendron NH, MacKenzie AE (2007) Distribution of neuronal apoptosis inhibitory protein in human tissues. J Histochem Cytochem 55(9):911-923. doi:10.1369/jhc.6A7144.2007

40. Diez E, Lee SH, Gauthier S, Yaraghi Z, Tremblay M, Vidal S, Gros P (2003) Bircle is the gene within the Lgn1 locus associated with resistance to Legionella pneumophila. Nat Genet 33(1):55-60. doi:10.1038/ng1065

41. Davoodi J, Lin L, Kelly J, Liston P, MacKenzie AE (2004) Neuronal apoptosis-inhibitory protein does not interact with Smac and requires ATP to bind caspase-9. J Biol Chem 279(39):40622-40628. doi:10.1074/jbc.M405963200

42. Holcik M, Thompson CS, Yaraghi Z, Lefebvre CA, MacKenzie AE, Korneluk RG (2000) The hippocampal neurons of neuronal apoptosis inhibitory protein 1 (NAIP1)-deleted mice display increased vulnerability to kainic acid-induced injury. Proc Natl Acad Sci USA 97(5):2286-2290. doi:10.1073/pnas.040469797

43. Vischioni B, van der Valk P, Span SW, Kruyt FA, Rodriguez JA, Giaccone G (2006) Expression and localization of inhibitor of apoptosis proteins in normal human tissues. Hum Pathol 37(1):78-86. doi:10.1016/j.humpath.2005.09.022

44. Hsieh WC, Chuang YT, Chiang IH, Hsu SC, Miaw SC, Lai MZ (2014) Inability to resolve specific infection generates innate immunodeficiency syndrome in Xiap-/- mice. Blood 124(18):2847-2857. doi:10.1182/blood-2014-03-564609

45. Kluger HM, McCarthy MM, Alvero AB, Sznol M, Ariyan S, Camp RL, Rimm DL, Mor G (2007) The X-linked inhibitor of apoptosis protein (XIAP) is up-regulated in metastatic melanoma, and XIAP cleavage by Phenoxodiol is associated with Carboplatin sensitization. J Trans Med 5:6. doi:10.1186/1479-5876-5-6

46. Hou Y, Allan LA, Clarke PR (2017) Phosphorylation of XIAP by CDK1-cyclin-B1 controls mitotic cell death. J Cell Sci 130(2):502-511. doi:10.1242/jcs. 192310

47. Tamm I, Richter S, Oltersdorf D, Creutzig U, Harbott J, Scholz F, Karawajew L, Ludwig WD, Wuchter C (2004) High expression levels of $\mathrm{x}$-linked inhibitor of apoptosis protein and survivin correlate with poor overall survival in childhood de novo acute myeloid leukemia. Clin Cancer Res 10(11):3737-3744. doi:10.1158/1078-0432.CCR-03-0642

48. Mufti AR, Burstein E, Duckett CS (2007) XIAP: cell death regulation meets copper homeostasis. Arch Biochem Biophys 463(2):168-174. doi:10.1016/j.abb.2007.01.033

49. Hussain AR, Uddin $\mathrm{S}$, Ahmed $\mathrm{M}, \mathrm{Bu} \mathrm{R}$, Ahmed SO, Abubaker J, Sultana M, Ajarim D, Al-Dayel F, Bavi PP, AlKuraya KS (2010) Prognostic significance of XIAP expression in DLBCL and effect of its inhibition on AKT signalling. J Pathol 222(2):180-190. doi:10.1002/path.2747

50. Liu J, Zhang D, Luo W, Yu Y, Yu J, Li J, Zhang X, Zhang B, Chen J, Wu XR, Rosas-Acosta G, Huang C (2011) X-linked inhibitor of apoptosis protein (XIAP) mediates cancer cell motility via Rho GDP dissociation inhibitor (RhoGDI)dependent regulation of the cytoskeleton. J Biol Chem 286(18):15630-15640. doi:10.1074/jbc.M110.176982

51. Mizutani Y, Nakanishi H, Li YN, Matsubara H, Yamamoto K, Sato N, Shiraishi T, Nakamura T, Mikami K, Okihara K, Takaha N, Ukimura O, Kawauchi A, Nonomura N, Bonavida B, Miki T (2007) Overexpression of XIAP expression in renal cell carcinoma predicts a worse prognosis. Int $\mathrm{J}$ Oncol 30(4):919-925

52. Hofer-Warbinek R, Schmid JA, Stehlik C, Binder BR, Lipp J, de Martin R (2000) Activation of NF-kappa B by XIAP, the $\mathrm{X}$ chromosome-linked inhibitor of apoptosis, in endothelial cells involves TAK1. J Biol Chem 275(29):22064-22068. doi:10.1074/jbc.M910346199

53. Pluta P, Jeziorski A, Cebula-Obrzut AP, Wierzbowska A, Piekarski J, Smolewski P (2015) Expression of IAP family proteins and its clinical importance in breast cancer patients. Neoplasma 62(4):666-673. doi:10.4149/neo_2015_080

54. Rigaud S, Fondaneche MC, Lambert N, Pasquier B, Mateo V, Soulas P, Galicier L, Le Deist F, Rieux-Laucat F, Revy P, Fischer A, de Saint Basile G, Latour S (2006) XIAP deficiency in humans causes an X-linked lymphoproliferative syndrome. Nature 444(7115):110-114. doi:10.1038/nature05257

55. Varfolomeev E, Blankenship JW, Wayson SM, Fedorova AV, Kayagaki N, Garg P, Zobel K, Dynek JN, Elliott LO, Wallweber HJ, Flygare JA, Fairbrother WJ, Deshayes K, Dixit VM, Vucic D (2007) IAP antagonists induce autoubiquitination of c-IAPs, NF-kappaB activation, and TNFalphadependent apoptosis. Cell 131(4):669-681. doi:10.1016/j. cell.2007.10.030

56. Ponnelle T, Chapusot C, Martin L, Bonithon-Kopp C, Bouvier AM, Plenchette S, Rageot D, Faivre J, Solary E, Piard F (2003) Subcellular expression of c-IAP1 and c-IAP2 in colorectal cancers: relationships with clinicopathological features and prognosis. Pathol Res Pract 199(11):723-731. doi:10.1078/0344-0338-00488

57. Kitamura H, Tsukamoto $\mathrm{T}$ (2008) Prognostic biomarkers of renal cell carcinoma: Recent advances. Indian J Urol 24(1):10 15. doi:10.4103/0970-1591.38596

58. Qi S, Mogi S, Tsuda H, Tanaka Y, Kozaki K, Imoto I, Inazawa J, Hasegawa S, Omura K (2008) Expression of cIAP-1 correlates with nodal metastasis in squamous cell carcinoma of the tongue. Int J Oral Maxillofac Surg 37(11):1047-1053. doi:10.1016/j.ijom.2008.06.004 
59. Samuel T, Okada K, Hyer M, Welsh K, Zapata JM, Reed JC (2005) cIAP1 Localizes to the nuclear compartment and modulates the cell cycle. Cancer Res 65(1):210-218

60. Tseng PH, Matsuzawa A, Zhang W, Mino T, Vignali DA, Karin M (2010) Different modes of ubiquitination of the adaptor TRAF3 selectively activate the expression of type I interferons and proinflammatory cytokines. Nat Immunol 11(1):70-75. doi:10.1038/ni.1819

61. Ferreira CG, van der Valk P, Span SW, Jonker JM, Postmus PE, Kruyt FA, Giaccone G (2001) Assessment of IAP (inhibitor of apoptosis) proteins as predictors of response to chemotherapy in advanced non-small-cell lung cancer patients. Ann Oncol 12(6):799-805

62. Bertrand MJ, Doiron K, Labbe K, Korneluk RG, Barker PA, Saleh M (2009) Cellular inhibitors of apoptosis cIAP1 and cIAP2 are required for innate immunity signaling by the pattern recognition receptors NOD1 and NOD2. Immunity 30(6):789-801. doi:10.1016/j.immuni.2009.04.011

63. Feoktistova M, Geserick P, Kellert B, Dimitrova DP, Langlais C, Hupe M, Cain K, MacFarlane M, Hacker G, Leverkus M (2011) cIAPs block Ripoptosome formation, a RIP1/caspase-8 containing intracellular cell death complex differentially regulated by cFLIP isoforms. Mol Cell 43(3):449-463. doi:10.1016/j.molcel.2011.06.011

64. Annunziata CM, Davis RE, Demchenko Y, Bellamy W, Gabrea A, Zhan F, Lenz G, Hanamura I, Wright G, Xiao W, Dave S, Hurt EM, Tan B, Zhao H, Stephens O, Santra M, Williams DR, Dang L, Barlogie B, Shaughnessy JD Jr, Kuehl WM, Staudt LM (2007) Frequent engagement of the classical and alternative NF-kappaB pathways by diverse genetic abnormalities in multiple myeloma. Cancer Cell 12(2):115130. doi:10.1016/j.ccr.2007.07.004

65. Stanculescu A, Bembinster LA, Borgen K, Bergamaschi A, Wiley E, Frasor J (2010) Estrogen promotes breast cancer cell survival in an inhibitor of apoptosis (IAP)-dependent manner. Horm Cancer 1(3):127-135. doi:10.1007/s12672-010-0018-6

66. Esposito I, Kleeff J, Abiatari I, Shi X, Giese N, Bergmann F, Roth W, Friess H, Schirmacher P (2007) Overexpression of cellular inhibitor of apoptosis protein 2 is an early event in the progression of pancreatic cancer. J Clin Pathol 60(8):885895. doi:10.1136/jcp.2006.038257

67. Jonsson G, Paulie S, Grandien A (2003) cIAP-2 block apoptotic events in bladder cancer cells. Anticancer Res 23(4):3311-3316

68. Rossi D, Fangazio M, Rasi S, Vaisitti T, Monti S, Cresta S, Chiaretti S, Del Giudice I, Fabbri G, Bruscaggin A, Spina V, Deambrogi C, Marinelli M, Fama R, Greco M, Daniele G, Forconi F, Gattei V, Bertoni F, Deaglio S, Pasqualucci L, Guarini A, Dalla-Favera R, Foa R, Gaidano G (2012) Disruption of BIRC3 associates with fludarabine chemorefractoriness in TP53 wild-type chronic lymphocytic leukemia. Blood 119(12):28542862. doi:10.1182/blood-2011-12-395673

69. Richter BW, Mir SS, Eiben LJ, Lewis J, Reffey SB, Frattini A, Tian L, Frank S, Youle RJ, Nelson DL, Notarangelo LD, Vezzoni P, Fearnhead HO, Duckett CS (2001) Molecular cloning of ILP-2, a novel member of the inhibitor of apoptosis protein family. Mol Cell Biol 21(13):4292-4301. doi:10.1128/ MCB.21.13.4292-4301.2001

70. Hauser HP, Bardroff M, Pyrowolakis G, Jentsch S (1998) A giant ubiquitin-conjugating enzyme related to IAP apoptosis inhibitors. J Cell Biol 141(6):1415-1422

71. Hao Y, Sekine K, Kawabata A, Nakamura H, Ishioka T, Ohata H, Katayama R, Hashimoto C, Zhang X, Noda T, Tsuruo T, Naito M (2004) Apollon ubiquitinates SMAC and caspase-9, and has an essential cytoprotection function. Nat Cell Biol 6(9):849-860. doi:10.1038/ncb1159
72. Pohl C, Jentsch S (2008) Final stages of cytokinesis and midbody ring formation are controlled by BRUCE. Cell 132(5):832-845. doi:10.1016/j.cell.2008.01.012

73. Bianchini M, Levy E, Zucchini C, Pinski V, Macagno C, De Sanctis P, Valvassori L, Carinci P, Mordoh J (2006) Comparative study of gene expression by cDNA microarray in human colorectal cancer tissues and normal mucosa. Int $\mathrm{J}$ Oncol 29(1):83-94

74. Tassi E, Zanon M, Vegetti C, Molla A, Bersani I, Perotti V, Pennati M, Zaffaroni N, Milella M, Ferrone S, Carlo-Stella C, Gianni AM, Mortarini R, Anichini A (2012) Role of Apollon in human melanoma resistance to antitumor agents that activate the intrinsic or the extrinsic apoptosis pathways. Clin Cancer Res 18(12):3316-3327. doi:10.1158/1078-0432.CCR-11-2232

75. Luk SU, Xue H, Cheng H, Lin D, Gout PW, Fazli L, Collins CC, Gleave ME, Wang Y (2014) The BIRC6 gene as a novel target for therapy of prostate cancer: dual targeting of inhibitors of apoptosis. Oncotarget 5(16):6896-6908. doi:10.18632/ oncotarget.2229

76. Ge C, Che L, Ren J, Pandita RK, Lu J, Li K, Pandita TK, Du C (2015) BRUCE regulates DNA double-strand break response by promoting USP8 deubiquitination of BRIT1. Proc Natl Acad Sci USA 112(11):E1210-E1219. doi:10.1073/pnas.1418335112

77. Chiou SK, Jones MK, Tarnawski AS (2003) Survivin: an antiapoptosis protein: its biological roles and implications for cancer and beyond. Med Sci 9(4):PI25-29

78. Garg H, Suri P, Gupta JC, Talwar GP, Dubey S (2016) Survivin: a unique target for tumor therapy. Cancer Cell Int 16:49. doi:10.1186/s12935-016-0326-1

79. Fukuda S, Mantel CR, Pelus LM (2004) Survivin regulates hematopoietic progenitor cell proliferation through p21WAF1/ Cip1-dependent and -independent pathways. Blood 103(1):120 127. doi:10.1182/blood-2003-05-1756

80. Tamm I, Wang Y, Sausville E, Scudiero DA, Vigna N, Oltersdorf T, Reed JC (1998) IAP-family protein survivin inhibits caspase activity and apoptosis induced by Fas (CD95), Bax, caspases, and anticancer drugs. Cancer Res 58(23):5315-5320

81. Caldas H, Jiang Y, Holloway MP, Fangusaro J, Mahotka C, Conway EM, Altura RA (2005) Survivin splice variants regulate the balance between proliferation and cell death. Oncogene 24(12):1994-2007. doi:10.1038/sj.onc. 1208350

82. Fukuda S, Pelus LM (2006) Survivin, a cancer target with an emerging role in normal adult tissues. Mol Cancer Ther 5(5):1087-1098. doi:10.1158/1535-7163.MCT-05-0375

83. Fernandez JG, Rodriguez DA, Valenzuela M, Calderon C, Urzua U, Munroe D, Rosas C, Lemus D, Diaz N, Wright MC, Leyton L, Tapia JC, Quest AF (2014) Survivin expression promotes VEGF-induced tumor angiogenesis via PI3K/Akt enhanced beta-catenin/Tcf-Lef dependent transcription. Mol Cancer 13:209. doi:10.1186/1476-4598-13-209

84. Chu XY, Chen LB, Wang JH, Su QS, Yang JR, Lin Y, Xue LJ, Liu XB, Mo XB (2012) Overexpression of survivin is correlated with increased invasion and metastasis of colorectal cancer. J Surg Oncol 105(6):520-528. doi:10.1002/jso.22134

85. Virrey JJ, Guan S, Li W, Schonthal AH, Chen TC, Hofman FM (2008) Increased survivin expression confers chemoresistance to tumor-associated endothelial cells. Am J Pathol 173(2):575585. doi:10.2353/ajpath.2008.071079

86. Vucic D, Stennicke HR, Pisabarro MT, Salvesen GS, Dixit VM (2000) ML-IAP, a novel inhibitor of apoptosis that is preferentially expressed in human melanomas. Curr Biol 10(21):1359-1366

87. Kim DK, Alvarado CS, Abramowsky CR, Gu L, Zhou M, Soe MM, Sullivan K, George B, Schemankewitz E, Findley HW (2005) Expression of inhibitor-of-apoptosis protein (IAP) livin by neuroblastoma cells: correlation with prognostic factors 
and outcome. Pediatr Dev Pathol 8(6):621-629. doi:10.1007/ s10024-005-4108-3

88. Yagihashi A, Asanuma K, Kobayashi D, Tsuji N, Shijubo Y, Abe S, Hirohashi Y, Torigoe T, Sato N, Watanabe N (2005) Detection of autoantibodies to livin and survivin in Sera from lung cancer patients. Lung Cancer 48(2):217-221. doi:10.1016/j.lungcan.2004.11.002

89. Yagihashi A, Asanuma K, Tsuji N, Torigoe T, Sato N, Hirata K, Watanabe N (2003) Detection of anti-livin antibody in gastrointestinal cancer patients. Clin Chem 49(7):1206-1208

90. Chen L, Ren GS, Li F, Sun SQ (2008) Expression of livin and vascular endothelial growth factor in different clinical stages of human esophageal carcinoma. World J Gastroenterol 14(37):5749-5754

91. Nedelcu T, Kubista B, Koller A, Sulzbacher I, Mosberger I, Arrich F, Trieb K, Kotz R, Toma CD (2008) Livin and Bcl-2 expression in high-grade osteosarcoma. J Cancer Res Clin Oncol 134(2):237-244. doi:10.1007/s00432-007-0276-Z

92. LaCasse EC, Mahoney DJ, Cheung HH, Plenchette S, Baird S, Korneluk RG (2008) IAP-targeted therapies for cancer. Oncogene 27(48):6252-6275. doi:10.1038/onc.2008.302

93. Cai Q, Sun H, Peng Y, Lu J, Nikolovska-Coleska Z, McEachern D, Liu L, Qiu S, Yang CY, Miller R, Yi H, Zhang T, Sun D, Kang S, Guo M, Leopold L, Yang D, Wang S (2011) A potent and orally active antagonist (SM-406/AT-406) of multiple inhibitor of apoptosis proteins (IAPs) in clinical development for cancer treatment. J Med Chem 54(8):2714-2726. doi:10.1021/jm101505d

94. Wang J, Wang L, Xia B, Yang C, Lai H, Chen X (2013) BSP gene silencing inhibits migration, invasion, and bone metastasis of MDA-MB-231BO human breast cancer cells. PLoS ONE 8(5):e62936. doi:10.1371/journal.pone.0062936

95. Perimenis P, Galaris A, Voulgari A, Prassa M, Pintzas A (2016) IAP antagonists Birinapant and AT-406 efficiently synergise with either TRAIL, BRAF, or BCL-2 inhibitors to sensitise BRAFV600E colorectal tumour cells to apoptosis. BMC Cancer 16:624. doi:10.1186/s12885-016-2606-5

96. Matzinger O, Viertl D, Tsoutsou P, Kadi L, Rigotti S, Zanna C, Wiedemann N, Vozenin MC, Vuagniaux G, Bourhis J (2015) The radiosensitizing activity of the SMAC-mimetic, Debio 1143 , is TNFalpha-mediated in head and neck squamous cell carcinoma. Radiother Oncol 116(3):495-503. doi:10.1016/j. radonc.2015.05.017

97. Qin Q, Zuo Y, Yang X, Lu J, Zhan L, Xu L, Zhang C, Zhu H, Liu J, Liu Z, Tao G, Dai S, Zhang X, Ma J, Cai J, Sun X (2014) Smac mimetic compound LCL161 sensitizes esophageal carcinoma cells to radiotherapy by inhibiting the expression of inhibitor of apoptosis protein. Tumour Biol 35(3):2565-2574. doi:10.1007/s13277-013-1338-2

98. Yang C, Wang H, Zhang B, Chen Y, Zhang Y, Sun X, Xiao G, Nan K, Ren H, Qin S (2016) LCL161 increases paclitaxel-induced apoptosis by degrading cIAP1 and cIAP2 in NSCLC. J Exp Clin Cancer Res 35(1):158. doi:10.1186/ s13046-016-0435-7

99. Beug ST, LaCasse EC, Korneluk RG (2014) Smac mimetics combined with innate immune stimuli create the perfect cytokine storm to kill tumor cells. Oncoimmunology 3:e28541. doi:10.4161/onci.28541

100. Flygare JA, Beresini M, Budha N, Chan H, Chan IT, Cheeti S, Cohen F, Deshayes K, Doerner K, Eckhardt SG, Elliott LO, Feng B, Franklin MC, Reisner SF, Gazzard L, Halladay J, Hymowitz SG, La H, LoRusso P, Maurer B, Murray L, Plise E, Quan C, Stephan JP, Young SG, Tom J, Tsui V, Um J, Varfolomeev E, Vucic D, Wagner AJ, Wallweber HJ, Wang L, Ware J, Wen Z, Wong H, Wong JM, Wong M, Wong S, Yu R, Zobel K, Fairbrother WJ (2012) Discovery of a potent small-molecule antagonist of inhibitor of apoptosis (IAP) proteins and clinical candidate for the treatment of cancer (GDC-0152). J Med Chem 55(9):4101-4113. doi:10.1021/ jm300060k

101. Tchoghandjian A, Souberan A, Tabouret E, Colin C, Denicolai E, Jiguet-Jiglaire C, El-Battari A, Villard C, Baeza-Kallee N, Figarella-Branger D (2016) Inhibitor of apoptosis protein expression in glioblastomas and their in vitro and in vivo targeting by SMAC mimetic GDC-0152. Cell Death Dis 7(8):e2325. doi:10.1038/cddis.2016.214

102. Benetatos CA, Mitsuuchi Y, Burns JM, Neiman EM, Condon SM, Yu G, Seipel ME, Kapoor GS, Laporte MG, Rippin SR, Deng Y, Hendi MS, Tirunahari PK, Lee YH, Haimowitz T, Alexander MD, Graham MA, Weng D, Shi Y, McKinlay MA, Chunduru SK (2014) Birinapant (TL32711), a bivalent SMAC mimetic, targets TRAF2-associated cIAPs, abrogates TNF-induced NF-kappaB activation, and is active in patientderived xenograft models. Mol Cancer Ther 13(4):867-879. doi:10.1158/1535-7163.MCT-13-0798

103. Allensworth JL, Sauer SJ, Lyerly HK, Morse MA, Devi GR (2013) Smac mimetic Birinapant induces apoptosis and enhances TRAIL potency in inflammatory breast cancer cells in an IAP-dependent and TNF-alpha-independent mechanism. Breast Cancer Res Treat 137(2):359-371. doi:10.1007/ s10549-012-2352-6

104. Janzen DM, Tiourin E, Salehi JA, Paik DY, Lu J, Pellegrini M, Memarzadeh S (2015) An apoptosis-enhancing drug overcomes platinum resistance in a tumour-initiating subpopulation of ovarian cancer. Nat Commun 6:7956. doi:10.1038/ncomms8956

105. Condon SM, Mitsuuchi Y, Deng Y, LaPorte MG, Rippin SR, Haimowitz T, Alexander MD, Kumar PT, Hendi MS, Lee YH, Benetatos CA, Yu G, Kapoor GS, Neiman E, Seipel ME, Burns JM, Graham MA, McKinlay MA, Li X, Wang J, Shi Y, Feltham R, Bettjeman B, Cumming MH, Vince JE, Khan N, Silke J, Day CL, Chunduru SK (2014) Birinapant, a smac-mimetic with improved tolerability for the treatment of solid tumors and hematological malignancies. J Med Chem 57(9):3666-3677. doi:10.1021/jm500176w

106. Krepler C, Chunduru SK, Halloran MB, He X, Xiao M, Vultur A, Villanueva J, Mitsuuchi Y, Neiman EM, Benetatos C, Nathanson KL, Amaravadi RK, Pehamberger H, McKinlay M, Herlyn M (2013) The novel SMAC mimetic birinapant exhibits potent activity against human melanoma cells. Clin Cancer Res 19(7):1784-1794. doi:10.1158/1078-0432.CCR-12-2518

107. Steinhart L, Belz K, Fulda S (2013) Smac mimetic and demethylating agents synergistically trigger cell death in acute myeloid leukemia cells and overcome apoptosis resistance by inducing necroptosis. Cell Death Dis 4:e802. doi:10.1038/cddis.2013.320

108. Belz K, Schoeneberger H, Wehner S, Weigert A, Bonig H, Klingebiel T, Fichtner I, Fulda S (2014) Smac mimetic and glucocorticoids synergize to induce apoptosis in childhood ALL by promoting ripoptosome assembly. Blood 124(2):240-250. doi:10.1182/blood-2013-05-500918

109. Brunckhorst MK, Lerner D, Wang S, Yu Q (2012) AT-406, an orally active antagonist of multiple inhibitor of apoptosis proteins, inhibits progression of human ovarian cancer. Cancer Biol Ther 13(9):804-811. doi:10.4161/cbt.20563

110. Tian A, Wilson GS, Lie S, Wu G, Hu Z, Hebbard L, Duan W, George J, Qiao L (2014) Synergistic effects of IAP inhibitor LCL161 and paclitaxel on hepatocellular carcinoma cells. Cancer Lett 351(2):232-241. doi:10.1016/j.canlet.2014.06.006

111. Eckhardt SG et al (2010) Phase I study evaluating the safety, tolerability, and pharmacokinetics (PK) of HGS1029, a small-molecule inhibitor of apoptosis protein (IAP), in patients (pts) with advanced solid tumors. Journal of Clinical Oncology 28(no. 15_suppl):2580-2580. doi:10.1200/jco.2010.28.15_suppl.2580 
112. Varfolomeev E, Alicke B, Elliott JM, Zobel K, West K, Wong H, Scheer JM, Ashkenazi A, Gould SE, Fairbrother WJ, Vucic D (2009) X chromosome-linked inhibitor of apoptosis regulates cell death induction by proapoptotic receptor agonists. J Biol Chem 284(50):34553-34560. doi:10.1074/jbc.M109.040139

113. Ma JJ, Chen BL, Xin XY (2009) XIAP gene downregulation by small interfering RNA inhibits proliferation, induces apoptosis, and reverses the cisplatin resistance of ovarian carcinoma. Eur J Obstet Gynecol Reprod Biol 146(2):222-226. doi:10.1016/j. ejogrb.2009.06.011

114. Li QX, Zhao J, Liu JY, Jia LT, Huang HY, Xu YM, Zhang Y, Zhang R, Wang CJ, Yao LB, Chen SY, Yang AG (2006) Survivin stable knockdown by siRNA inhibits tumor cell growth and angiogenesis in breast and cervical cancers. Cancer Biol Ther 5(7):860-866

115. Schimmer AD, Estey EH, Borthakur G, Carter BZ, Schiller GJ, Tallman MS, Altman JK, Karp JE, Kassis J, Hedley DW, Brandwein J, Xu W, Mak DH, LaCasse E, Jacob C, Morris SJ, Jolivet J, Andreeff M (2009) Phase I/II trial of AEG35156 $\mathrm{X}$-linked inhibitor of apoptosis protein antisense oligonucleotide combined with idarubicin and cytarabine in patients with relapsed or primary refractory acute myeloid leukemia. J Clin Oncol 27(28):4741-4746. doi:10.1200/JCO.2009.21.8172

116. Carter BZ, Mak DH, Morris SJ, Borthakur G, Estey E, Byrd AL, Konopleva M, Kantarjian H, Andreeff M (2011) XIAP antisense oligonucleotide (AEG35156) achieves target knockdown and induces apoptosis preferentially in CD34+ 38-cells in a phase 1/2 study of patients with relapsed/refractory AML. Apoptosis 16(1):67-74. doi:10.1007/s10495-010-0545-1

117. Mahadevan D, Chalasani P, Rensvold D, Kurtin S, Pretzinger C, Jolivet J, Ramanathan RK, Von Hoff DD, Weiss GJ (2013) Phase I trial of AEG35156 an antisense oligonucleotide to XIAP plus gemcitabine in patients with metastatic pancreatic ductal adenocarcinoma. Am J Clin Oncol 36(3):239-243. doi:10.1097/COC.0b013e3182467a13

118. Song Z, Yao X, Wu M (2003) Direct interaction between survivin and Smac/DIABLO is essential for the anti-apoptotic activity of survivin during taxol-induced apoptosis. J Biol Chem 278(25):23130-23140. doi:10.1074/jbc.M300957200

119. Du C, Fang M, Li Y, Li L, Wang X (2000) Smac, a mitochondrial protein that promotes cytochrome c-dependent caspase activation by eliminating IAP inhibition. Cell 102(1):33-42

120. Chai J, Du C, Wu JW, Kyin S, Wang X, Shi Y (2000) Structural and biochemical basis of apoptotic activation by Smac/DIABLO. Nature 406(6798):855-862. doi:10.1038/35022514

121. Guicciardi ME, Mott JL, Bronk SF, Kurita S, Fingas CD, Gores GJ (2011) Cellular inhibitor of apoptosis 1 (cIAP-1) degradation by caspase 8 during TNF-related apoptosis-inducing ligand (TRAIL)-induced apoptosis. Exp Cell Res 317(1):107-116. doi:10.1016/j.yexcr.2010.10.005

122. Welsh K, Milutinovic S, Ardecky RJ, Gonzalez-Lopez M, Ganji SR, Teriete P, Finlay D, Riedl S, Matsuzawa S, Pinilla C, Houghten R, Vuori K, Reed JC, Cosford ND (2016) Characterization of potent SMAC mimetics that sensitize cancer cells to TNF family-induced apoptosis. PLoS ONE 11(9):e0161952. doi:10.1371/journal.pone.0161952

123. Dohi T, Beltrami E, Wall NR, Plescia J, Altieri DC (2004) Mitochondrial survivin inhibits apoptosis and promotes tumorigenesis. J Clin Invest 114(8):1117-1127. doi:10.1172/JCI22222

124. Mehrotra S, Languino LR, Raskett CM, Mercurio AM, Dohi T, Altieri DC (2010) IAP regulation of metastasis. Cancer cell 17(1):53-64. doi:10.1016/j.ccr.2009.11.021

125. Arora V, Cheung HH, Plenchette S, Micali OC, Liston P, Korneluk RG (2007) Degradation of survivin by the X-linked inhibitor of apoptosis (XIAP)-XAF1 complex. J Biol Chem 282(36):26202-26209. doi:10.1074/jbc.M700776200
126. Kanwar JR, Kamalapuram SK, Kanwar RK (2011) Targeting survivin in cancer: the cell-signalling perspective. Drug Discov Today 16(11-12):485-494. doi:10.1016/j. drudis.2011.04.001

127. Ausserlechner MJ, Hagenbuchner J (2016) Mitochondrial survivin: an Achilles' heel in cancer chemoresistance. Mol Cell Oncol 3(2):e1076589. doi:10.1080/23723556.2015.1076589

128. Yu CC, Wu PJ, Hsu JL, Ho YF, Hsu LC, Chang YJ, Chang HS, Chen IS, Guh JH (2013) Ardisianone, a natural benzoquinone, efficiently induces apoptosis in human hormone-refractory prostate cancers through mitochondrial damage stress and survivin downregulation. Prostate 73(2):133-145. doi:10.1002/ pros. 22548

129. Sun H, Nikolovska-Coleska Z, Yang CY, Xu L, Liu M, Tomita Y, Pan H, Yoshioka Y, Krajewski K, Roller PP, Wang S (2004) Structure-based design of potent, conformationally constrained Smac mimetics. J Am Chem Soc 126(51):16686-16687. doi:10.1021/ja047438+

130. Lu J, Bai L, Sun H, Nikolovska-Coleska Z, McEachern D, Qiu S, Miller RS, Yi H, Shangary S, Sun Y, Meagher JL, Stuckey JA, Wang S (2008) SM-164: a novel, bivalent Smac mimetic that induces apoptosis and tumor regression by concurrent removal of the blockade of cIAP-1/2 and XIAP. Cancer Res 68(22):9384-9393. doi:10.1158/0008-5472.CAN-08-2655

131. Hossbach J, Michalsky E, Henklein P, Jaeger M, Daniel PT, Preissner R (2009) Inhibiting the inhibitors: retro-inverso Smac peptides. Peptides 30(12):2374-2379. doi:10.1016/j. peptides.2009.08.001

132. Lau R, Pratt MA (2012) The opposing roles of cellular inhibitor of apoptosis proteins in cancer. ISRN Oncol 2012:928120. doi: $10.5402 / 2012 / 928120$

133. Suzuki Y, Nakabayashi Y, Nakata K, Reed JC, Takahashi $\mathrm{R}$ (2001) X-linked inhibitor of apoptosis protein (XIAP) inhibits caspase- 3 and -7 in distinct modes. J Biol Chem 276(29):27058-27063. doi:10.1074/jbc.M102415200

134. Hird AW, Aquila BM, Hennessy EJ, Vasbinder MM, Yang B (2015) Small molecule inhibitor of apoptosis proteins antagonists: a patent review. Expert Opin Ther Pat 25(7):755-774. doi: 10.1517/13543776.2015.1041922

135. Chessari G, Buck IM, Day JE, Day PJ, Iqbal A, Johnson CN, Lewis EJ, Martins V, Miller D, Reader M, Rees DC, Rich SJ, Tamanini E, Vitorino M, Ward GA, Williams PA, Williams G, Wilsher NE, Woolford AJ (2015) Fragment-based drug discovery targeting inhibitor of apoptosis proteins: discovery of a non-alanine lead series with dual activity against cIAP1 and XIAP. J Med Chem 58(16):6574-6588. doi:10.1021/acs. jmedchem.5b00706

136. Yang C, Novack DV (2013) Anti-cancer IAP antagonists promote bone metastasis: a cautionary tale. J Bone Miner Metab 31(5):496-506. doi:10.1007/s00774-013-0479-0

137. Yang C, Davis JL, Zeng R, Vora P, Su X, Collins LI, Vangveravong S, Mach RH, Piwnica-Worms D, Weilbaecher KN, Faccio R, Novack DV (2013) Antagonism of inhibitor of apoptosis proteins increases bone metastasis via unexpected osteoclast activation. Cancer Discov 3(2):212-223. doi:10.1158/21598290.CD-12-0271

138. Schirmer M, Trentin L, Queudeville M, Seyfried F, Demir S, Tausch E, Stilgenbauer S, Eckhoff SM, Meyer LH, Debatin KM (2016) Intrinsic and chemo-sensitizing activity of SMACmimetics on high-risk childhood acute lymphoblastic leukemia. Cell Death Dis 7:e2052. doi:10.1038/cddis.2015.382

139. Maas C, Tromp JM, van Laar J, Thijssen R, Elias JA, Malara A, Krippner-Heidenreich A, Silke J, van Oers MH, Eldering E (2013) CLL cells are resistant to smac mimetics because of an inability to form a ripoptosome complex. Cell Death Dis 4:e782. doi:10.1038/cddis.2013.305 
140. Petersen SL, Wang L, Yalcin-Chin A, Li L, Peyton M, Minna J, Harran P, Wang X (2007) Autocrine TNFalpha signaling renders human cancer cells susceptible to Smac-mimeticinduced apoptosis. Cancer Cell 12(5):445-456. doi:10.1016/j. ccr.2007.08.029

141. Tenev T, Bianchi K, Darding M, Broemer M, Langlais C, Wallberg F, Zachariou A, Lopez J, MacFarlane M, Cain K, Meier $\mathrm{P}$ (2011) The ripoptosome, a signaling platform that assembles in response to genotoxic stress and loss of IAPs. Mol Cell 43(3):432-448. doi:10.1016/j.molcel.2011.06.006

142. Darding M, Feltham R, Tenev T, Bianchi K, Benetatos C, Silke J, Meier P (2011) Molecular determinants of Smac mimetic induced degradation of cIAP1 and cIAP2. Cell Death Differ 18(8):1376-1386. doi:10.1038/cdd.2011.10

143. Balakrishnan K, Fu M, Onida F, Wierda WG, Keating MJ, Gandhi V (2016) Reactivation of Smac-mediated apoptosis in chronic lymphocytic leukemia cells: mechanistic studies of Smac mimetic. Oncotarget 7(26):39458-39472. doi:10.18632/ oncotarget. 8462

144. Knights AJ, Fucikova J, Pasam A, Koernig S, Cebon J (2013) Inhibitor of apoptosis protein (IAP) antagonists demonstrate divergent immunomodulatory properties in human immune subsets with implications for combination therapy. Cancer Immunol Immunother 62(2):321-335. doi:10.1007/ s00262-012-1342-1

145. Laukens B, Jennewein C, Schenk B, Vanlangenakker N, Schier A, Cristofanon S, Zobel K, Deshayes K, Vucic D, Jeremias I, Bertrand MJ, Vandenabeele P, Fulda S (2011) Smac mimetic bypasses apoptosis resistance in FADD- or caspase-8-deficient cells by priming for tumor necrosis factor alpha-induced necroptosis. Neoplasia 13(10):971-979

146. Wagner L, Marschall V, Karl S, Cristofanon S, Zobel K, Deshayes K, Vucic D, Debatin KM, Fulda S (2013) Smac mimetic sensitizes glioblastoma cells to Temozolomide-induced apoptosis in a RIP1- and NF-kappaB-dependent manner. Oncogene 32(8):988-997. doi:10.1038/onc.2012.108

147. Li L, Thomas RM, Suzuki H, De Brabander JK, Wang X, Harran PG (2004) A small molecule Smac mimic potentiates TRAIL- and TNFalpha-mediated cell death. Science 305(5689):1471-1474. doi:10.1126/science.1098231

148. Yang L, Mashima T, Sato S, Mochizuki M, Sakamoto H, Yamori T, Oh-Hara T, Tsuruo T (2003) Predominant suppression of apoptosome by inhibitor of apoptosis protein in non-small cell lung cancer H460 cells: therapeutic effect of a novel polyarginine-conjugated Smac peptide. Cancer Res 63(4):831-837

149. Arnt CR, Chiorean MV, Heldebrant MP, Gores GJ, Kaufmann SH (2002) Synthetic Smac/DIABLO peptides enhance the effects of chemotherapeutic agents by binding XIAP and cIAP1 in situ. J Biol Chem 277(46):44236-44243. doi:10.1074/jbc. M207578200

150. Bockbrader KM, Tan M, Sun Y (2005) A small molecule Smacmimic compound induces apoptosis and sensitizes TRAIL- and etoposide-induced apoptosis in breast cancer cells. Oncogene 24(49):7381-7388. doi:10.1038/sj.onc.1208888

151. Ling X, Cao S, Cheng Q, Keefe JT, Rustum YM, Li F (2012) A novel small molecule FL118 that selectively inhibits survivin, Mcl-1, XIAP and cIAP2 in a p53-independent manner, shows superior antitumor activity. PLoS ONE 7(9):e45571. doi:10.1371/journal.pone.0045571

152. Ling X, Li F (2013) An intravenous (i.v.) route-compatible formulation of FL118, a survivin, Mcl-1, XIAP, and cIAP2 selective inhibitor, improves FL118 antitumor efficacy and therapeutic index (TI). Am J Trans Res 5(2):139-154

153. Chen KF, Lin JP, Shiau CW, Tai WT, Liu CY, Yu HC, Chen PJ, Cheng AL (2012) Inhibition of Bcl-2 improves effect of LCL161, a SMAC mimetic, in hepatocellular carcinoma cells. Biochem Pharmacol 84(3):268-277. doi:10.1016/j. bcp.2012.04.023

154. West AC, Martin BP, Andrews DA, Hogg SJ, Banerjee A, Grigoriadis G, Johnstone RW, Shortt J (2016) The SMAC mimetic, LCL-161, reduces survival in aggressive MYC-driven lymphoma while promoting susceptibility to endotoxic shock. Oncogenesis 5:e216. doi:10.1038/oncsis.2016.26

155. Micheau O, Shirley S, Dufour F (2013) Death receptors as targets in cancer. Br J Pharmacol 169(8):1723-1744. doi:10.1111/ bph. 12238

156. Wang S, El-Deiry WS (2003) TRAIL and apoptosis induction by TNF-family death receptors. Oncogene 22(53):8628-8633. doi:10.1038/sj.onc.1207232

157. Ozoren N, El-Deiry WS (2002) Defining characteristics of Types I and II apoptotic cells in response to TRAIL. Neoplasia 4(6):551-557. doi:10.1038/sj.neo.7900270

158. van Roosmalen IA, Quax WJ, Kruyt FA (2014) Two deathinducing human TRAIL receptors to target in cancer: similar or distinct regulation and function? Biochem Pharmacol 91(4):447-456. doi:10.1016/j.bcp.2014.08.010

159. Falschlehner C, Schaefer U, Walczak H (2009) Following TRAIL's path in the immune system. Immunology 127(2):145154. doi:10.1111/j.1365-2567.2009.03058.x

160. LeBlanc H, Lawrence D, Varfolomeev E, Totpal K, Morlan J, Schow P, Fong S, Schwall R, Sinicropi D, Ashkenazi A (2002) Tumor-cell resistance to death receptor-induced apoptosis through mutational inactivation of the proapoptotic Bcl-2 homolog Bax. Nat Med 8(3):274-281. doi:10.1038/ nm0302-274

161. Parrish AB, Freel CD, Kornbluth S (2013) Cellular mechanisms controlling caspase activation and function. Cold Spring Harbor Perspect Biol. doi:10.1101/cshperspect.a008672

162. Dai Y, Liu M, Tang W, Li Y, Lian J, Lawrence TS, Xu L (2009) A Smac-mimetic sensitizes prostate cancer cells to TRAILinduced apoptosis via modulating both IAPs and NF-kappaB. BMC Cancer 9:392. doi:10.1186/1471-2407-9-392

163. McManus DC, Lefebvre CA, Cherton-Horvat G, St-Jean M, Kandimalla ER, Agrawal S, Morris SJ, Durkin JP, Lacasse EC (2004) Loss of XIAP protein expression by RNAi and antisense approaches sensitizes cancer cells to functionally diverse chemotherapeutics. Oncogene 23(49):8105-8117. doi:10.1038/ sj.onc. 1207967

164. Lee TJ, Jung EM, Lee JT, Kim S, Park JW, Choi KS, Kwon TK (2006) Mithramycin A sensitizes cancer cells to TRAILmediated apoptosis by down-regulation of XIAP gene promoter through Sp1 sites. Mol Cancer Ther 5(11):2737-2746. doi:10.1158/1535-7163.MCT-06-0426

165. Jost PJ, Grabow S, Gray D, McKenzie MD, Nachbur U, Huang DC, Bouillet P, Thomas HE, Borner C, Silke J, Strasser A, Kaufmann T (2009) XIAP discriminates between type I and type II FAS-induced apoptosis. Nature 460(7258):1035-1039. doi:10.1038/nature08229

166. Cheng J, Hylander BL, Baer MR, Chen X, Repasky EA (2006) Multiple mechanisms underlie resistance of leukemia cells to Apo2 Ligand/TRAIL. Mol Cancer Ther 5(7):1844-1853. doi:10.1158/1535-7163.MCT-06-0050

167. Dechant MJ, Fellenberg J, Scheuerpflug CG, Ewerbeck V, Debatin KM (2004) Mutation analysis of the apoptotic "deathreceptors" and the adaptors TRADD and FADD/MORT-1 in osteosarcoma tumor samples and osteosarcoma cell lines. Int JCancer 109(5):661-667. doi:10.1002/ijc.20008

168. Merino D, Lalaoui N, Morizot A, Schneider P, Solary E, Micheau O (2006) Differential inhibition of TRAIL-mediated DR5-DISC formation by decoy receptors 1 and 2. Mol Cell Biol 26(19):7046-7055. doi:10.1128/MCB.00520-06 
169. Singh TR, Shankar S, Chen X, Asim M, Srivastava RK (2003) Synergistic interactions of chemotherapeutic drugs and tumor necrosis factor-related apoptosis-inducing ligand/Apo-2 ligand on apoptosis and on regression of breast carcinoma in vivo. Cancer Res 63(17):5390-5400

170. Timur M, Cort A, Ozdemir E, Sarikcioglu SB, Sanlioglu S, Sanlioglu AD, Ozben T (2015) Bleomycin induced sensitivity to TRAIL/Apo-2L-mediated apoptosis in human seminomatous testicular cancer cells is correlated with upregulation of death receptors. Anticancer Agents Med Chem 15(1):99-106

171. Venza I, Visalli M, Oteri R, Teti D, Venza M (2014) Class I-specific histone deacetylase inhibitor MS-275 overrides TRAIL-resistance in melanoma cells by downregulating c-FLIP. Int Immunopharmacol 21(2):439-446. doi:10.1016/j. intimp.2014.05.024

172. Nathwani SM, Greene LM, Butini S, Campiani G, Williams DC, Samali A, Szegezdi E, Zisterer DM (2016) The pyrrolo1,5-benzoxazepine, PBOX-15, enhances TRAILinduced apoptosis by upregulation of DR5 and downregulation of core cell survival proteins in acute lymphoblastic leukaemia cells. Int $\mathbf{J}$ Oncol 49(1):74-88. doi:10.3892/ijo.2016.3518

173. Son JK, Varadarajan S, Bratton SB (2010) TRAIL-activated stress kinases suppress apoptosis through transcriptional upregulation of MCL-1. Cell Death Differ 17(8):1288-1301. doi:10.1038/cdd.2010.9

174. Subramanian A, Andronache A, Li YC, Wade M (2016) Inhibition of MARCH5 ubiquitin ligase abrogates MCL1dependent resistance to $\mathrm{BH} 3$ mimetics via NOXA. Oncotarget 7(13):15986-16002. doi:10.18632/oncotarget.7558

175. Gupta SC, Reuter S, Phromnoi K, Park B, Hema PS, Nair M, Aggarwal BB (2011) Nimbolide sensitizes human colon cancer cells to TRAIL through reactive oxygen species- and ERKdependent up-regulation of death receptors, p53, and Bax. J Biol Chem 286(2):1134-1146. doi:10.1074/jbc.M110.191379

176. Babykutty S, S PP, J NR, Kumar MA, Nair MS, Srinivas P, Gopala S (2012) Nimbolide retards tumor cell migration, invasion, and angiogenesis by downregulating MMP-2/9 expression via inhibiting ERK1/2 and reducing DNA-binding activity of NF-kappaB in colon cancer cells. Mol Carcinog 51(6):475-490. doi: $10.1002 / \mathrm{mc} .20812$

177. Gillissen B, Wendt J, Richter A, Richter A, Muer A, Overkamp T, Gebhardt N, Preissner R, Belka C, Dorken B, Daniel PT (2010) Endogenous Bak inhibitors Mcl-1 and Bcl-xL: differential impact on TRAIL resistance in Bax-deficient carcinoma. $\mathrm{J}$ Cell Biol 188(6):851-862. doi:10.1083/jcb.200912070

178. Ortiz-Ferron G, Yerbes R, Eramo A, Lopez-Perez AI, De Maria R, Lopez-Rivas A (2008) Roscovitine sensitizes breast cancer cells to TRAIL-induced apoptosis through a pleiotropic mechanism. Cell Res 18(6):664-676. doi:10.1038/cr.2008.54

179. Rosato RR, Almenara JA, Coe S, Grant S (2007) The multikinase inhibitor sorafenib potentiates TRAIL lethality in human leukemia cells in association with Mcl-1 and cFLIPL downregulation. Cancer Res 67(19):9490-9500. doi:10.1158/00085472.CAN-07-0598

180. van Delft MF, Wei AH, Mason KD, Vandenberg CJ, Chen L, Czabotar PE, Willis SN, Scott CL, Day CL, Cory S, Adams JM, Roberts AW, Huang DC (2006) The BH3 mimetic ABT-737 targets selective Bcl-2 proteins and efficiently induces apoptosis via Bak/Bax if Mcl-1 is neutralized. Cancer Cell 10(5):389399. doi:10.1016/j.ccr.2006.08.027

181. Gillissen B, Richter A, Richter A, Overkamp T, Essmann F, Hemmati PG, Preissner R, Belka C, Daniel PT (2013) Targeted therapy of the XIAP/proteasome pathway overcomes TRAILresistance in carcinoma by switching apoptosis signaling to a Bax/Bak-independent 'type I' mode. Cell Death Dis 4:e643. doi:10.1038/cddis.2013.67

182. Huang Y, Yang X, Xu T, Kong Q, Zhang Y, Shen Y, Wei Y, Wang G, Chang KJ (2016) Overcoming resistance to TRAILinduced apoptosis in solid tumor cells by simultaneously targeting death receptors, c-FLIP and IAPs. Int J Oncol 49(1):153163. doi:10.3892/ijo.2016.3525

183. Morizot A, Merino D, Lalaoui N, Jacquemin G, Granci V, Iessi E, Lanneau D, Bouyer F, Solary E, Chauffert B, Saas P, Garrido C, Micheau O (2011) Chemotherapy overcomes TRAILR4-mediated TRAIL resistance at the DISC level. Cell Death Differ 18(4):700-711. doi:10.1038/cdd.2010.144

184. Seo OW, Kim JH, Lee KS, Lee KS, Kim JH, Won MH, Ha KS, Kwon YG, Kim YM (2012) Kurarinone promotes TRAILinduced apoptosis by inhibiting NF-kappaB-dependent cFLIP expression in HeLa cells. Exp Mol Med 44(11):653-664. doi:10.3858/emm.2012.44.11.074

185. Kang Z, Chen JJ, Yu Y, Li B, Sun SY, Zhang B, Cao L (2011) Drozitumab, a human antibody to death receptor 5 , has potent antitumor activity against rhabdomyosarcoma with the expression of caspase- 8 predictive of response. Clin Cancer Res 17(10):3181-3192. doi:10.1158/1078-0432.CCR-10-2874

186. Zinonos I, Labrinidis A, Liapis V, Hay S, Panagopoulos V, Denichilo M, Ponomarev V, Ingman W, Atkins GJ, Findlay DM, Zannettino AC, Evdokiou A (2014) Doxorubicin overcomes resistance to drozitumab by antagonizing inhibitor of apoptosis proteins (IAPs). Anticancer Res 34(12):7007-7020

187. Obexer P, Ausserlechner MJ (2014) X-linked inhibitor of apoptosis protein: a critical death resistance regulator and therapeutic target for personalized cancer therapy. Front Oncol 4:197. doi:10.3389/fonc.2014.00197

188. Noonan AM, Bunch KP, Chen JQ, Herrmann MA, Lee JM, Kohn EC, O'Sullivan CC, Jordan E, Houston N, Takebe N, Kinders RJ, Cao L, Peer CJ, Figg WD, Annunziata CM (2016) Pharmacodynamic markers and clinical results from the phase 2 study of the SMAC mimetic birinapant in women with relapsed platinum-resistant or -refractory epithelial ovarian cancer. Cancer 122(4):588-597. doi:10.1002/cncr.29783 